\title{
APROXIMACIÓN A LA LEGISLACIÓN PROTECTORA DEL DEUDOR HIPOTECARIO
}

\author{
María Elena Sánchez Collado
}

doi: 10.18543/ed-64(2)-2016pp259-304

\begin{abstract}
Sumario: I. Introducción. II. Real Decreto-Ley 8/2011, De 1 DE JULIO, DE MEDIDAS DE APOYO A LOS DEUDORES HIPOTECARIOS. III. EL REAL DECRETO-LEY 6/2012, DE 9 DE MARZO, DE MEDIDAS URGENTES DE PROTECCIÓN DE DEUDORES HIPOTECARIOS SIN RECURSOS Y EL REAL DECRETO-LEY DE 15 DE NOVIEMBRE DE 2012 DE MEDIDAS URGENTES PARA REFORZAR LA PROTECCIÓN A LOS DEUDORES HIPOTECARIOS. IV. LA LEY 1/2013, DE 14 DE MAYO, DE MEDIDAS PARA REFORZAR LA PROTECCIÓN A LOS DEUDORES HIPOTECARIOS, REESTRUCTURACIÓN DE DEUDA, Y ALQUILER SOCIAL Y LA LEY 8/2013, DE 26 DE JUNIO, DE REHABILITACIÓN, REGENERACIÓN Y RENOVACIÓN URBANAS. V. EL RDL 1/2015 DE 27 DE FEBRERO Y LA LEY 25/2015, DE 28 DE JULIO. LA SITUACIÓN DEL DEUDOR HIPOTECARIO EN LA ACTUALIDAD. CONCLUSIONES Y REFLEXIONES.
\end{abstract}

\section{INTRODUCCIÓN*}

En el presente trabajo pretendemos hacer un análisis descriptivo y crítico de las distintas reformas legislativas adoptadas en los últimos años, de grave crisis económica en España, encaminadas a deparar al deudor hipotecario la necesaria protección, partiendo de la primera iniciativa representada por el Real Decreto-Ley 8/2011, de 1 de Julio, hasta culminar con las más recientes disposiciones en el momento de escribir estas páginas: el

${ }^{*}$ El presente trabajo se realiza en el marco del proyecto de $\mathrm{I}+\mathrm{D}+\mathrm{i}$ con referencia DER2014-53497-P, financiado por el Ministerio de Economía y Competitividad. 
RDL 1/2015 de 27 de febrero y la Ley 25/2015, de 28 de julio. Estimamos que resulta indispensable un examen exhaustivo de todas ellas para alcanzar a dilucidar si, fundamentalmente a lo largo de la última legislatura en España (2012-2015), se ha ultimado o no el objetivo de conferir al deudor hipotecario la protección adecuada en estos tiempos de crisis extremadamente convulsos y complejos, que han tenido una especial incidencia precisamente en el ámbito del mercado inmobiliario y el sobreendeudamiento de particulares.

\section{REAL DECRETO-LEY 8/2011, DE 1 DE JULIO, DE MEDIDAS DE APOYO A LOS DEUDORES HIPOTECARIOS}

Cuando la crisis económica iniciada en 2007 empezó a mostrar su rostro más perverso, especialmente a partir del 2009, cuando numerosas personas perdieron sus empleos y, en consecuencia, se empezaron a encontrar en dificultades para afrontar el pago de sus deudas hipotecarias y comenzaron a multiplicarse los impagados, el Gobierno se vio en la obligación de intervenir para tratar de amortiguar las peores consecuencias de tales impagos, como es la definitiva pérdida de la vivienda objeto de la garantía hipotecaria $\mathrm{y}$, en general, la reducción de los medios de subsistencia de las familias sobreendeudadas.

La primera iniciativa protectora de los deudores hipotecarios sobreendeudados fue el Real Decreto-ley 6/2010, de 9 de abril, de Medidas para el Impulso de la Recuperación Económica y el Empleo (Pacto de Zurbano), que aumentaba el importe del salario inembargable cuando, tras una ejecución hipotecaria, el resultado de la venta no fuese suficiente para saldar la deuda y hubiese que continuar con la ejecución sobre el patrimonio del deudor ${ }^{1}$; salario mínimo inembargable que se elevaría aún más con el Real Decreto-ley 8/2011, de 1 de julio, de Medidas de Apoyo a los Deudores Hipotecarios, de Control del Gasto Público, y cancelación de deudas con empresas y autónomos contraidas por las entidades locales, de fomento de la actividad empresarial e impulso de la rehabilitación y de simplificación, cuyo objetivo, según la Exposición de motivos, era garantizar que, en caso de producirse una ejecución hipotecaria por impago, los deudores recibieran una

${ }^{1}$ Cfr. M. ${ }^{a}$ B. SÁinz CANTERo CAparrós, «La evolución de la posición del deudor hipotecario desde el Pacto de Zurbano hasta la ley 1/2013 de 14 de mayo: del favor creditoris cum hypotheca al principio de protección del consumidor en el tráfico inmobiliario» en La protección del deudor hipotecario. Aproximación a la Ley de Medidas para reforzar la protección a los deudores hipotecarios, reestructuración de deuda y alquiler social, J.A. Escartín Ipiéns y M. ${ }^{\circ}$ A. Martos Calabrús (Coords.), A. Núñez Iglesias (Dir.) (Granada: Comares, 2014), 7 ss. 
contraprestación por el inmueble, que les permitiera saldar o reducir al máximo posible la deuda remanente ${ }^{2}$.

En la Exposición de Motivos de este último Real Decreto-Ley 8/2011, de 1 de julio, se parte de la idea de que la situación en la que está el mercado inmobiliario en España repercute directamente en aquellos que contrajeron préstamos hipotecarios cuando los inmuebles tenían una valoración muy alta y que ahora se encuentran ante la dramática situación de no poder hacer frente al préstamo hipotecario. Ante esta situación, dice el legislador muy acertadamente que son precisas medidas para proteger a las familias que poseen menos ingresos y además, en lo que se refiere a las ejecuciones hipotecarias, se debe garantizar que se realicen sin dar lugar a situaciones abusivas, así como el abaratamiento de los bienes sujetos a la ejecución hipotecaria, eso sí, todo ello «manteniendo plenamente, los elementos fundamentales de garantía de los préstamos y, con ellos, de la seguridad y solvencia de nuestro sistema hipotecario», máxima ésta que se reiteraría en los posteriores cuerpos normativos, dirigidos a la protección del deudor hipotecario. Era claro el mensaje de una necesaria actuación urgente que protegiera los derechos del deudor hipotecario y que eliminase la incertidumbre que de alguna manera sobrevolaba la ejecución hipotecaria. Esa actuación se plasmaría por este Real Decreto-Ley en dos aspectos: de un lado, se retocaría el mínimo de inembargabilidad y, de otro, el porcentaje de adjudicación del bien al banco en el procedimiento de ejecución.

Respecto del mínimo de inembargabilidad, señalaba la Exposición de motivos que, con el fin de moderar el impacto negativo de la crisis económica sobre los ciudadanos más vulnerables y, en particular, sobre aquellos con cargas familiares, se elevaría el umbral de inembargabilidad cuando el precio obtenido por la venta de la vivienda habitual hipotecada en un procedimiento de ejecución hipotecaria fuese insuficiente para cubrir el crédito garantizado ${ }^{3}$.

${ }^{2}$ Cfr. R. Catena Real, «Las recientes reformas legislativas ante la problemática planteada por los deudores hipotecarios. ¿Son suficientes?», Diario La Ley 8428 (25 de Noviembre de 2014): 1-33. En este artículo se hace un recorrido por las distintas reformas legislativas sucedidas desde el año 2011 con el afán de propiciar al deudor hipotecario la necesaria protección de la que en su opinión, a la vista de todo lo acontecido en estos últimos años, carece.

3 Y así, si bien con carácter general, el mínimo inembargable de cualquier deudor coincide con el salario mínimo interprofesional (SMI), a partir de este Real Decreto-Ley, según preceptúa su artículo 1 subsistente en la actualidad: En el caso de que, de acuerdo con lo dispuesto en el artículo 129 de la Ley Hipotecaria, el precio obtenido por la venta de la vivienda habitual hipotecada sea insuficiente para cubrir el crédito garantizado, en la ejecución forzosa posterior basada en la misma deuda, la cantidad inembargable establecida en el artículo 607.1 de la Ley de Enjuiciamiento Civil se incrementará en un 50 por 
Y, en cuanto al porcentaje de adjudicación en subasta, la Exposición de Motivos señala que «se modifica la Ley de Enjuiciamiento Civil para garantizar que en caso de producirse una ejecución hipotecaria por impago, los deudores recibirán una contraprestación adecuada por el inmueble, que les permita anular o reducir al máximo la deuda remanente». La adjudicación del acreedor en subasta del inmueble hipotecado, nunca se llevará a cabo por un importe inferior al $60 \%$ del valor de tasación. Se trata con ello de evitar el despojo del deudor, de manera que la entidad de crédito nunca podrá adjudicarse el inmueble por un porcentaje inferior, sea cual sea la cuantía de la deuda total. Además, se fomenta un mayor número de pujas en las subastas con el fin de que el precio sea más justo; para ello, se reduce hasta el $20 \%$ el depósito exigido a los postores para participar en la subasta. Es una medida muy positiva tendente a aumentar el número de postores en las subastas para la mejor adjudicación del bien hipotecado. Y para la consecución de estos objetivos se procedería a la modificación de los artículos 669, 670 y 671 de la Ley 1/2000, de 7 de enero, de Enjuiciamiento Civil ${ }^{4}$.

ciento y además en otro 30 por ciento del salario mínimo interprofesional por cada miembro del núcleo familiar que $\mathrm{n}^{\circ}$ disponga de ingresos propios regulares, salario o pensión superiores al salario mínimo interprofesional.

${ }^{4}$ El apartado 1 del art. 669 en su redacción dada en dicha fecha, que exige a los postores para participar en la subasta el depósito previo del 20 por ciento del valor que se haya dado a los bienes, sería modificado por virtud de la Ley 1/2013, de 14 de mayo, de suerte que dicho depósito previo es, en la actualidad, únicamente del 5 por ciento del valor que se hubiese dado a los bienes, como se verá más adelante en el texto y en nota 48. El segundo párrafo del apartado 4 del art. 670, que no sido modificado con posterioridad, disponía lo siguiente: que, transcurrido el indicado plazo sin que el ejecutado realice lo previsto en el párrafo anterior, el ejecutante podrá, en el plazo de cinco días, pedir la adjudicación del inmueble por el $70 \%$ de dicho valor o por la cantidad que se le deba por todos los conceptos, siempre que esta cantidad sea superior al sesenta por ciento de su valor de tasación y a la mejor postura; y finalmente, el art. 671 establecería: «Si en el acto de la subasta no hubiere ningún postor, podrá el acreedor pedir la adjudicación de los bienes por cantidad igual o superior al sesenta por ciento de su valor de tasación. Cuando el acreedor, en el plazo de veinte días, no hiciere uso de esa facultad, el Secretario judicial procederá al alzamiento del embargo, a instancia del ejecutado». Este precepto ha sido nuevamente redactado por virtud de la Ley 1/2013, de 14 de mayo, de medidas para reforzar la protección a los deudores hipotecarios: "Si en el acto de la subasta no hubiere ningún postor, podrá el acreedor, en el plazo de veinte días, pedir la adjudicación del bien. Si no se tratare de la vivienda habitual del deudor, el acreedor podrá pedir la adjudicación por el 50 por cien del valor por el que el bien hubiera salido a subasta o por la cantidad que se le deba por todos los conceptos. Si se tratare de la vivienda habitual del deudor, la adjudicación se hará por importe igual al 70 por cien del valor por el que el bien hubiese salido a subasta o si la cantidad que se le deba por todos los conceptos es inferior a ese porcentaje, por el 60 por cien». Vid. al respecto infra en el texto. 


\section{EL REAL DECRETO-LEY 6/2012, DE 9 DE MARZO, DE MEDIDAS URGENTES DE PROTECCIÓN DE DEUDORES HIPOTECARIOS SIN RECURSOS Y EL REAL DECRETO-LEY DE 15 DE NOVIEMBRE DE 2012 DE MEDIDAS URGENTES PARA REFORZAR LA PROTECCIÓN A LOS DEUDORES HIPOTECARIOS}

Con posterioridad, el Real Decreto-ley 6/2012 de 9 de marzo, de protección de deudores hipotecarios sin recursos, aplicable a los contratos de préstamo o crédito garantizados con hipoteca, vigentes a la fecha de su entrada en vigor, cuyo deudor se encontrase situado en el umbral de exclusión, introduciría algunos mecanismos dirigidos a la reestructuración de la deuda hipotecaria de quienes no pudiesen atender su pago y a la flexibilización de la ejecución de la garantía real, entre ellos la novación obligatoria de la deuda para los acreedores que se adhieran voluntariamente al Código de Buenas Prácticas (CBP), aunque solo en los contratos de préstamo o crédito garantizados por hipoteca para la adquisición de vivienda cuyo precio no sobrepase unos límites variables según la población ${ }^{5}$. El CBP permite no obstante, que el acreedor adherido al mismo mejore las previsiones que en él se contemplan, de suerte que su aplicación puede extenderse también a deudores que se encuentren fuera del umbral de exclusión.

En el precitado Real Decreto-ley 6/2012 de 9 de marzo, la reestructuración de la deuda hipotecaria se procura aplicando a los préstamos una carencia en la amortización del capital, una reducción del tipo de interés durante cuatro años (Anexo CBP 1. i), y una ampliación del plazo total de amortización hasta cuarenta años (Anexo CBP 1. ii). Se ordena además la limitación del interés moratorio al resultante de sumar a los intereses remuneratorios pactados en el préstamo un 2,5\% sobre el capital pendiente de préstamo (artículo 4 Real Decreto-ley), y se posibilita en último término si resultasen insuficientes las medidas sobre la deuda, que el acreedor acepte la dación en pago solicitada por el deudor, de modo que con la entrega de la vivienda habitual queden canceladas la deuda, la responsabilidad personal del deudor y la de terceros (Anexo CBP 3). Se permite además que las familias puedan permanecer en su vivienda, quedando suspendido el lanzamiento durante un mínimo de dos años, con la satisfacción de una renta anual equivalente al $3 \%$ del importe de la deuda pendiente en el momento en que se verifique la dación en pago (Anexo CBP 3 c)).

${ }_{5}$ El texto del mencionado Real Decreto-ley quedó modificado por la Ley 1/2013, Ley $8 / 2013$, de 26 de junio, de rehabilitación, regeneración y renovación urbanas, por el R.Dley $1 / 2015$, de 27 de febrero de mecanismo de segunda oportunidad, reducción de carga financiera y otras medidas de orden social y por la Ley $25 / 2015$, de 28 de julio, de mecanismo de segunda oportunidad, reducción de la carga financiera y otras medidas de orden social. 
Destaca también en el citado RD la reforma que se opera en el procedimiento extrajudicial de ejecución hipotecaria, aproximándolo al judicial y reduciendo a una sola subasta las tres previstas por el Reglamento Hipotecario, encomendando la Disposición final tercera del Real Decreto-ley el desarrollo reglamentario de la ejecución extrajudicial que debe contemplar entre otras previsiones la subasta electrónica ${ }^{6}$.

En el mencionado Real Decreto-ley 6/2012, de 9 de marzo ${ }^{7}$ se crearía el CBP como un código de autodisciplina que establece un comportamiento al que pueden adherirse los bancos y entidades de crédito y al que se dota de instrumentos para su control ${ }^{8}$. Ya desde la aprobación del Real Decreto-ley 6/2012, de 9 de marzo se levantaron numerosas críticas contra el mismo por una parte, porque una vez que la entidad bancaria se somete voluntariamente a él mediante una Comunicación de adhesión dirigida a la Secretaría General del Tesoro y Política Financiera, queda vinculada a sujetar su actuación al mismo y, por otra, porque es solo aplicable a hipotecas constituidas sobre la primera vivienda, que sea la residencia habitual y cuando todos los miembros de la unidad familiar perciban unas rentas muy bajas (por cuanto que según el artículo 3 del Real Decreto-ley 6/2012, de 9 de marzo únicamente pueden resultar beneficiados los deudores que se encuentren en el denominado «umbral de exclusión» y que cumplimenten los requisitos establecidos en el mismo precepto ${ }^{9}$ ).

${ }^{6}$ Con relación al procedimiento ejecutivo extrajudicial de ejecución hipotecaria, vid. A. NúÑEZ IGLESIAS, «Alternativa a la ejecución hipotecaria judicial en La venta extrajudicial de bien hipotecado», A. Núñez Iglesias (Coord.) (Granada: Comares, 2012), 1-32 y S. ÁlVAREZ ROYO-VILLANOVA, «La ejecución hipotecaria extrajudicial: problemas prácticos y propuestas de reforma», también en La venta extrajudicial de bien hipotecado... 73101.

7 Cfr. Pedro A. Munar Bernat, Códigos de buenas prácticas, reestructuración de la deuda y dación en pago, en La protección del deudor hipotecario... cit. $77 \mathrm{~s}$.

8 Para M. ${ }^{\mathrm{a}}$ del Mar Gómez LozAno, (cfr. La protección del consumidor en la comercialización de préstamos hipotecarios en La protección del deudor hipotecario... 185) el CBP aprobado por Real Decreto-ley 6/2012, de 9 de marzo se ciñe en orden a su contenido al diseño de unas medidas previas a la ejecución hipotecaria dirigidas a la reestructuración de deudas, por lo que su ámbito de aplicación se circunscribe a la fase de ejecución. Existen además códigos éticos aplicables a la actividad de comercialización en el ámbito publicitario. Así los bancos y las cajas son anunciantes «socios» de Autocontrol (Asociación para la Autorregulación de la Comunicación Comercial). Y en este sentido, la Norma Tercera de la Circular 6/2010, de 28 de septiembre del Banco de España, a entidades de crédito y entidades de pago, sobre publicidad de los servicios y productos bancarios, estimula la adhesión a organismos de autorregulación de la actividad publicitaria que velen por su cumplimiento.

9 Según el artículo 3 del Real Decreto-ley 6/2012: «1. Se considerarán situados en el umbral de exclusión aquellos deudores de un crédito o préstamo garantizado con hipoteca 
El artículo 5.2 del Real Decreto-ley 6/2012, de 9 de marzo en su redacción original prescribía que el CBP se refería exclusivamente a las hipotecas constituidas en garantía de préstamos o créditos concedidos para la compraventa de viviendas con unos precios máximos de adquisición, que necesariamente tuvieron que ser ampliados en virtud de la Ley $1 / 2013$, salvo para aquellos casos en que se pretendiese emplear la vía de la dación en pago ${ }^{10}$.

Como resulta del apartado 4 del artículo 5 del citado Real Decreto-ley 6/2012, de 9 de marzo, la aplicación de las previsiones contenidas en el CBP comporta una novación contractual en tanto que se produce, ex artículo 1203 del Código civil, una alteración del objeto o de las condiciones del contrato, pudiendo cualquiera de las partes compeler a la otra a la formalización en escritura pública de la novación del contrato resultante de la aplicación de las previsiones contenidas en el $\mathrm{CBP}^{11}$.

sobre su vivienda habitual, cuando concurran en ellos todas las circunstancias siguientes: a) Que todos los miembros de la unidad familiar carezcan de rentas derivadas del trabajo o de actividades económicas. A estos efectos se entenderá por unidad familiar la compuesta por el deudor, su cónyuge no separado legalmente o pareja de hecho inscrita y los hijos con independencia de su edad que residan en la vivienda. b) Que la cuota hipotecaria resulte superior al 60 por cien de los ingresos netos que perciba el conjunto de los miembros de la unidad familiar. c) Que el conjunto de los miembros de la unidad familiar carezca de cualesquiera otros bienes o derechos patrimoniales suficientes con los que hacer frente a la deuda. d) Que se trate de un crédito o préstamo garantizado con hipoteca que recaiga sobre la única vivienda en propiedad del deudor y concedido para la adquisición de la misma. e) Que se trate de un crédito o préstamo que carezca de otras garantías, reales o personales o, en el caso de existir estas últimas, que en todos los garantes concurran las circunstancias expresadas en las letras b) y c). f) En el caso de que existan codeudores que no formen parte de la unidad familiar, deberán estar incluidos en las circunstancias a), b) y c) anteriores.» Este precepto como veremos, sería con posterioridad redactado por virtud del Real Decreto-ley 1/2015, de 27 de febrero, de mecanismo de segunda oportunidad.

${ }^{10}$ Cfr. Pedro A. Munar Bernat, Códigos de buenas prácticas, reestructuración de la deuda y dación en pago... 79-80. Como veremos, este precepto sería nuevamente redactado por virtud del Real Decreto-ley 1/2015, de 27 de febrero, y de la Ley 25/2015, de 28 de julio.

${ }^{11}$ En relación a este apartado, cuya redacción se mantiene tras las reformas llevadas a cabo en el 2015, lo que no se acaba de entender es que se contemple como una simple potestad atribuida a ambas partes, la formalización en escritura pública de la novación del contrato resultante. $\mathrm{N} .^{\circ}$ debemos olvidar que nos encontramos ante un contrato de préstamo o de crédito garantizado con hipoteca, que en su momento se instrumentó en escritura pública para que pudiera acceder al Registro de la Propiedad el derecho real de hipoteca, que es de inscripción constitutiva, de suerte que debiera haberse exigido en cualquier caso la constancia en escritura pública de la novación producida. Compartimos aquí la opinión manifestada por Pedro A. MunAR BERNAT, Códigos de buenas prácticas, reestructuración de la deuda y dación en pago... cit. p. 81 . 
En el ANEXO del Real Decreto-ley 6/2012, de 9 de marzo, que contiene el CBP para la reestructuración viable de las deudas con garantía hipotecaria sobre la vivienda habitual, se prevén tres tipos de medidas que deberá al menos estudiar la entidad que voluntariamente se someta al mismo:

1) La primera de ellas, contemplada en el artículo 1 del Anexo consiste en la reestructuración de deudas hipotecarias, que únicamente podrá solicitar el deudor que se encuentre en el umbral de exclusión y siempre que, después de haberse iniciado el procedimiento de ejecución, no se haya producido el anuncio de subasta. Después de presentada la solicitud, la entidad dispone del plazo de un mes para ofrecer y notificar un plan de reestructuración. En cualquier caso, conforme a lo establecido en la letra c) del número 1 del Anexo, en el documento en que se detalle el plan de reestructuración la entidad deberá advertir, si fuera inviable, si cabe la posibilidad de instar la quita, o si no se dan las circunstancias para solicitarla ${ }^{12}$.

2) En relación a la segunda medida, cabe indicar que en el número 2 del Anexo, se establece que «los deudores para los que el plan de reestructuración resulte inviable, podrán solicitar una quita en el capital pendiente de amortización, que la entidad tendrá facultad para aceptar o rechazar en el plazo de un mes a contar desde la acreditación de la inviabilidad del plan de reestructuración.» Conforme se desprende del número 2 del Anexo, la solicitud de quita podrá ser realizada por hasta tres grupos de deudores, que en cualquier caso deberán cumplir los requisitos del artículo 3.2 del RDL:

a) Deudor al que el plan de reestructuración ofrecido resulta inviable, estimándose plan de reestructuración inviable aquel que establezca una cuota hipotecaria mensual superior al $50 \%$ de los ingresos que perciban conjuntamente todos los miembros de la unidad familiar.

b) Deudor hipotecario incurso en procedimiento de ejecución hipotecaria en el que ya se ha producido el anuncio de subasta al que no se le ha podido ofrecer el plan de reestructuración, por impedirlo el punto $1 \mathrm{a}$ ), $2 .^{\circ}$ párrafo, del Anexo.

${ }^{12}$ En relación a este precepto que mantiene su redacción originaria después de su parcial modificación por virtud del R.D ley 1/2015, de 27 de febrero, coincidimos con Pedro A. Munar Bernat, (cfr. Códigos de buenas prácticas, reestructuración de la deuda y dación en pago... 83), en estimar que ningún sentido tiene que la entidad ofrezca un plan de reestructuración si es inviable. 
c) Los deudores que no pueden optar por la dación en pago por presentar la vivienda cargas posteriores a la hipoteca que se pretende extinguir ${ }^{13}$.

3) $Y$ en relación finalmente a la última medida sustitutiva de la ejecución hipotecaria consistente en la dación en pago, que se contempla en el número 3 del Anexo, indicaremos que la viabilidad de la misma presenta dificultades, porque al igual que para la hipótesis de la quita, es necesario que se cumplan los requisitos del artículo 3.2 del Real Decreto-ley 6/2012, de 9 de marzo, y que además, concurran los siguientes supuestos, de acuerdo con lo establecido en el artículo 3 del mismo Real Decreto-ley en su relación con los artículos 1 y 2 del precitado Anexo, a saber:

a) Que no haya resultado viable el plan de reestructuración y que la entidad haya rechazado la quita solicitada.

b) Que en el procedimiento de ejecución no se haya anunciado la subasta.

c) Que la vivienda no esté gravada con cargas posteriores ${ }^{14}$.

${ }^{13}$ Después de la reforma de 2015, se han mantenido los diversos métodos de cálculo alternativo que la normativa ofrece a la entidad a la hora de plantear la posible quita y que se contemplan en el número 2 del Anexo.

${ }^{14}$ Con la mencionada reglamentación lo que pretende el legislador es evitar que el acreedor no solo tenga que dar carta de pago por toda la deuda, sino que además se vea obligado a quedarse con una finca que esté gravada a favor de un tercero. El número 3 del Anexo que contempla la dación en pago, no ha sufrido modificación alguna tras de la reforma llevada a cabo en el 2015, En el indicado precepto se establece: 3. Medidas sustitutivas de la ejecución hipotecaria: dación en pago de la vivienda habitual. a) En el plazo de doce meses desde la solicitud de la reestructuración, los deudores comprendidos en el ámbito de aplicación del artículo 2 del Real Decreto-ley 6/2012, de 9 de marzo, de medidas urgentes de protección de deudores hipotecarios sin recursos, para los que la reestructuración y las medidas complementarias, en su caso, no resulten viables conforme a lo establecido en el apartado 2, podrán solicitar la dación en pago de su vivienda habitual en los términos previstos en este apartado. En estos casos la entidad estará obligada a aceptar la entrega del bien hipotecado por parte del deudor, a la propia entidad o tercero que ésta designe, quedando definitivamente cancelada la deuda. b) La dación en pago supondrá la cancelación total de la deuda garantizada con hipoteca y de las responsabilidades personales del deudor y de terceros frente a la entidad por razón de la misma deuda. c) El deudor, si así lo solicitara en el momento de pedir la dación en pago, podrá permanecer durante un plazo de dos años en la vivienda en concepto de arrendatario, satisfaciendo una renta anual del 3 por cien del importe total de la deuda en el momento de la dación. Durante dicho plazo el impago de la renta devengará un interés de demora del 10 por cien. d) Las entidades podrán pactar con los deudores la cesión de una parte de la plusvalía generada por la enajenación de la vivienda, en contraprestación por la colaboración que éste pueda prestar en dicha transmisión. e) Esta medida no será aplicable en los supuestos que 
El Real Decreto-ley de 15 de noviembre de 2012 introduciría una nueva medida de carácter temporal y excepcional con la finalidad de impedir el lanzamiento de la vivienda en todos los casos de adjudicación al acreedor o a un tercero, cuando los deudores se encontraran en riesgo de exclusión social. La expresada norma aplicable en circunstancias extraordinarias, tenía como única finalidad, según señala su Exposición de Motivos, la de evitar que la adversidad económica de las familias, los condene finalmente a su exclusión social ${ }^{15}$.

se encuentren en procedimiento de ejecución en los que ya se haya anunciado la subasta, o en los que la vivienda esté gravada con cargas posteriores.

15 Según el artículo 1 de este Real Decreto-ley de 15 de noviembre de 2012: 1. Hasta transcurridos dos años desde la entrada en vigor de este real decreto-ley, no procederá el lanzamiento cuando en un proceso judicial o extrajudicial de ejecución hipotecaria se hubiera adjudicado al acreedor, o a persona que actúe por su cuenta, la vivienda habitual de personas que se encuentren en los supuestos de especial vulnerabilidad y en las circunstancias económicas previstas en este artículo; 2. 2. Los supuestos de especial vulnerabilidad a los que se refiere el apartado anterior son: a) Familia numerosa, de conformidad con la legislación vigente. b) Unidad familiar monoparental con dos hijos a cargo. c) Unidad familiar de la que forme parte un menor de tres años. d) Unidad familiar en la que alguno de sus miembros tenga declarada discapacidad superior al 33 por ciento, situación de dependencia o enfermedad que le incapacite acreditadamente de forma permanente para realizar una actividad laboral. e) Unidad familiar en la que el deudor hipotecario se encuentre en situación de desempleo y haya agotado las prestaciones por desempleo; f) Unidad familiar con la que convivan, en la misma vivienda, una o más personas que estén unidas con el titular de la hipoteca o su cónyuge por vínculo de parentesco hasta el tercer grado de consanguinidad o afinidad, y que se encuentren en situación personal de discapacidad, dependencia, enfermedad grave que les incapacite acreditadamente de forma temporal o permanente para realizar una actividad laboral; g) Unidad familiar en que exista una víctima de violencia de género, conforme a lo establecido en la legislación vigente, en el caso de que la vivienda objeto de lanzamiento constituyan su domicilio habitual. 3. Para que sea de aplicación lo previsto en el apartado 1 deberán concurrir, además de los supuestos de especial vulnerabilidad previstos en el apartado anterior, las circunstancias económicas siguientes: a) Que el conjunto de los ingresos de los miembros de la unidad familiar no supere el límite de tres veces el Indicador Público de Renta de Efectos Múltiples. b) Que, en los cuatro años anteriores al momento de la solicitud, la unidad familiar haya sufrido una alteración significativa de sus circunstancias económicas, en términos de esfuerzo de acceso a la vivienda; c) Que la cuota hipotecaria resulte superior al 50 por cien de los ingresos netos que perciba el conjunto de los miembros de la unidad familiar. d) Que se trate de un crédito o préstamo garantizado con hipoteca que recaiga sobre la única vivienda en propiedad del deudor y concedido para la adquisición de la misma.4. A los efectos de lo previsto en este artículo se entenderá: a) Que se ha producido una alteración significativa de las circunstancias económicas cuando el esfuerzo que represente la carga hipotecaria sobre la renta familiar se haya multiplicado por al menos 1,5.b) Por unidad familiar la compuesta por el deudor, su cónyuge no separado legalmente o pareja de hecho inscrita y los hijos, con independencia de su edad, que residan en la 
Diversos colectivos de juristas valoraron duramente este RD-ley, observando entre otros defectos concretos, la estricta consideración de los deudores en el umbral de exclusión (quedaban fuera las familias con niños mayores de 3 años o los jubilados, por ejemplo). Se insistió en que la situación económica requería una profunda reforma de la $\mathrm{LH}$, la limitación legal del contenido del contrato, el control judicial de las condiciones de la contratación (cláusulas abusivas de las entidades bancarias, sobrevaloraciones perjudiciales a los ejecutados, intereses leoninos...), cuestionándose asimismo el procedimiento extrajudicial hipotecario, carente de las garantías del procedimiento judicial, estimándose asimismo que todas las medidas que se contemplan en el Real Decreto-ley 6/2012 de 9 de marzo tienen en realidad carácter potestativo para los acreedores, de suerte que la indicada norma no parece alterar en absoluto, la naturaleza pro creditoris del sistema de contratación y ejecución hipotecarias ${ }^{16}$. Insistentemente se reclamaba la posibilidad de ordenar la dación en pago en los casos en que los valores de tasación reflejados en el contrato, fuesen muy lejanos a los de la subasta y adjudicación, de modo que el deudor ejecutado perdiese el bien por el que se hipotecó y quedase además endeudado de por vida ${ }^{17}$. Ciertamente no hay norma en nuestro ordenamiento que respalde una dación en pago no voluntaria para el acreedor. La voluntad del acreedor es condición, tanto para aplicar el artículo $140 \mathrm{LH}$, como el artículo 3 del CBP anexo al Real Decreto-ley 6/2012, de 9 de marzo precitado, ya que es de adhesión voluntaria por parte de las entidades de crédito. Y es jurisprudencia consolidada, la que desestima las alegaciones del deudor que pretende que la ejecución no continúe sobre su patrimonio, cuando la ejecución del bien hipotecado no haya sido suficiente para saldar por completo la deuda, aunque diverso

vivienda, incluyendo los vinculados por una relación de tutela, guarda o acogimiento familiar.

${ }^{16}$ Suscribimos aquí la opinión mantenida por M. ${ }^{\mathrm{a}}$ B. SÁINZ CANTERo CAPARRÓs (cfr., La evolución de la posición del deudor hipotecario... 12-13.

${ }_{17}$ Véase sobre este particular el informe del Defensor del pueblo del 2012: «crisis económica y deudores hipotecarios: actuaciones y propuestas del Defensor del Pueblo (enero 2012)»: <https://www.defensordelpueblo.es/informe-monografico/crisis-economica-y-deudores-hipotecarios-actuaciones-y-propuestas-del-defensor-del-pueblo-enero-2012>; cfr. S. TORRES EsCÁMEZ, Protección del deudor hipotecario y principios jurídicos, en La protección del deudor hipotecario... 1-6, quien nos indica en su trabajo que los tres principios jurídicos que de una manera más esencial resultan aplicables a la situación de deuda hipotecaria son el de seguridad jurídica, en su sentido de seguridad del ordenamiento, seguridad de los derechos, seguridad del tráfico y certeza de las relaciones jurídicas; el de responsabilidad patrimonial consagrado en el artículo 1911 del Código civil, que es el mayor obstáculo que se opone a la dación en pago obligatoria y retroactiva; y en tercer lugar, el principio de protección del consumidor, en nuestro caso del consumidor hipotecario. 
es sin embargo el criterio manifestado en algunas decisiones judiciales, como por ejemplo en el Auto de la Audiencia Provincial de Gerona de 16 de septiembre de 2011, que admite las daciones en pago en ejecuciones hipotecarias ${ }^{18}$.

La protección del deudor en la ejecución representa la última fase temporal en que se puede encontrar un deudor hipotecario en dificultades. Desde las plataformas de afectados se condenó sin paliativos las reformas precitadas llevadas a cabo fundamentalmente en el 2012, por estimar que no representaban una solución al problema social planteado. Desde el ámbito de la banca y también por muchos juristas, en cambio, se señaló que la modificación por el legislador de las relaciones jurídicas contractuales implica un ataque a la seguridad jurídica que pone en riesgo la futura concesión de crédito hipotecario ${ }^{19}$. De suerte que nuestro sistema hipotecario que nos parecía tan satisfactorio, sería objeto de un cuestionamiento general provocado por la crisis del que no se libraría tampoco nuestro procedimiento ejecutivo, al estimar la sentencia de 14 de marzo del TJUE (As. C-415/11) ${ }^{20}$ que el sistema español de ejecución hipotecaria es contrario a la normativa europea, al no

${ }_{18}$ En el expresado Auto de la Audiencia Provincial de Gerona de 16 de septiembre de 2011 , se indica en efecto, que «se olvida a veces que en la interpretación y aplicación de las leyes los tribunales deben buscar aquella respuesta que, sin contravenirlas, sea más acorde con una decisión justa, que es lo que, en última instancia, la ciudadanía espera de un «tribunal de justicia». En relación al mismo, sin embargo M. ángeles PARRA, (cfr. «Contratación y vivienda en la crisis económica», en Le obbligazioni e i contratti nel tempo della crisi económica. Italia e Spagna a confronto, a cura di Giuseppe Grisi, Jovene Editore, Napoli, 2014, 50 ss.). estima, coincidiendo con el parecer de numerosos expertos, que limitar la responsabilidad hipotecaria al inmueble que se ofrece como garantía de la devolución del préstamo implica un encarecimiento del crédito y una disminución de las hipotecas concedidas. Y alude al necesario desarrollo del concepto de crédito responsable, que implica una evaluación de la solvencia del deudor por parte de las entidades de crédito, tal y como se contempla entre otras disposiciones en la Ley 6/2011, de 24 de junio, de contratos de crédito al consumo La A. reflexiona asimismo sobre la conveniencia de que el desistimiento contractual reconocido a los consumidores en algunos sectores, que contempla el artículo 28 de la Ley 16/2011 de crédito al consumo, y que permite a éstos reflexionar sobre la conveniencia de vincularse definitivamente al contrato, se reconozca también en el ámbito del crédito inmobiliario, posibilidad ésta explícitamente rechazada por el artículo 10 de la Ley 22/2007, de 11 de julio.

19 Cfr. Segismundo Álvarez Royo-Villanova, Protección del deudor hipotecario en la ejecución de la garantía, en La protección del deudor hipotecario... 145 ss., quien estima que ambas visiones son parciales y no permiten hacer un juicio razonable de la reforma. Por una parte, el problema de los deudores hipotecarios no es exclusivamente un problema social; y por otra, la seguridad jurídica no es un valor absoluto, sino que ha de ser evaluado en relación con la justicia.

$20 \mathrm{Vid}$. texto en <http://curia.europa.eu/juris/document/document. jsf?docid=135024\&doclang=ES>. 
permitir una fase de oposición en la que el deudor pueda discutir el carácter abusivo de una cláusula de la hipoteca que se ejecuta ${ }^{21}$.

\section{LA LEY 1/2013, DE 14 DE MAYO, DE MEDIDAS PARA REFORZAR LA PROTECCIÓN A LOS DEUDORES HIPOTECARIOS, REESTRUCTURACIÓN DE DEUDA, Y ALQUILER SOCIAL Y LA LEY 8/2013, DE 26 DE JUNIO, DE
REHABILITACIÓN, REGENERACIÓN Y RENOVACIÓN
URBANAS}

1. A todas las carencias y críticas manifestadas en relación con la normativa precedente pretendió responder la Ley $1 / 2013$, de 14 de mayo, que intentó solventar todas las expresadas cuestiones, comenzando con unas medidas temporales y coyunturales, ordenando la suspensión inmediata y por un plazo de dos años de los lanzamientos de las familias que se encontrasen en una situación de especial riesgo de exclusión (capítulo I). La expresada

${ }^{21}$ No han faltado autores que han estimado que quizá procedería imaginación y apertura a otras posibles alternativas que el Derecho comparado nos depara en el ámbito de los procedimientos y formas de ejecución hipotecaria (Cfr. Álvaro NúÑEZ IGLESIAS, «Alternativa a la ejecución hipotecaria judicial», en La venta extrajudicial... 1-31), quien considera que la ejecución hipotecaria judicial y en definitiva la subasta judicial distan mucho todavía de representar un trámite eficaz, aunque parcialmente trataron de paliarse por la actual Ley 1/2000, de 7 de enero, de Enjuiciamiento Civil y sus sucesivas reformas. Los Derechos europeos privilegian la vía extrajudicial y ofrecen posibilidades que desconoce o evita el Derecho español, como son entre otras el pacto comisorio y la venta por el propio deudor que contempla el artículo 2201. 1 del Code civil. También podría defenderse el interés o ventaja comparativa del procedimiento ejecutivo extrajudicial frente al judicial en atención a su agilidad o rapidez, lo que favorece al desarrollo de crédito, a los acreedores y a los propios deudores (cfr. Manuel GonZÁLEZ-MENESES GARCÍA-VALDECASAS, «Sobre la legitimidad del procedimiento notarial de ejecución hipotecaria», en $L a$ venta extrajudicial de bien hipotecado... pp. 33-71), legitimidad del indicado procedimiento que en modo alguno debe presuponer una merma de las garantías jurídicas correspondientes a todos los sujetos implicados, en particular el deudor ejecutado. La posibilidad en general de este procedimiento extrajudicial de ejecución no ha estado sin embargo exenta de dudas, habiendo existido incluso pronunciamientos judiciales del máximo rango que han negado la validez de alguno de estos procedimientos por falta de cobertura legal. Parece sorprendente que en un sistema de contratación en donde impera como regla general la libertad de forma, si bien nace directamente de la ley la posibilidad de acudir a un procedimiento judicial de ejecución directa sobre la finca hipotecada, en cambio la viabilidad de entablar el procedimiento extrajudicial de ejecución, no nacería de la ley, sino de un expreso pacto de las partes en el título de constitución de la hipoteca, característica del indicado procedimiento que subsiste tras de la modificación del artículo 129 LH por virtud de la Ley 1/2013, de 14 de mayo, de medidas para reforzar la protección a los deudores hipotecarios, reestructuración de deuda y alquiler social. 
disposición también prevé la ampliación del colectivo de personas en situación de vulnerabilidad, que pueden beneficiarse del fondo social de vivienda, contemplándose además en el capítulo II («Medidas de mejora del mercado hipotecario») importantes límites en la contratación.

Con referencia a la suspensión de los lanzamientos en la ejecución hipotecaria, la expresada materia que anteriormente contemplaba el Real DecretoLey 27/2012, en la actualidad se regula en el artículo 1 de la Ley 1/2013, de 14 de mayo, modificado en sus apartados 1, 2 y 3 por el R.D.-ley 1/2015, de 27 de febrero de mecanismo de segunda oportunidad y con posterioridad, por el artículo 3 de la Ley 25/2015, de 28 de julio, de mecanismo de segunda oportunidad, reducción de la carga financiera y otras medidas de orden social ${ }^{22}$. Deudor e hipotecante, como se desprende de los términos del artículo $1.3 \mathrm{~d}$ ), tienen que ser la misma persona, por cuanto que el crédito o préstamo garantizado con hipoteca que recaiga sobre la única vivienda en propiedad del deudor tiene que haberse concedido para la adquisición de la misma ${ }^{23}$. Se prevé en esta Ley $1 / 2013$ que la protección brindada a las unidades compuestas por dos ascendientes y un solo hijo, quede limitada a que el hijo sea menor de tres años ${ }^{24}$. El derecho concedido al deudor es el de continuar en el uso de la vivienda gratuitamente por tiempo determinado. El título, estimamos, no puede ser otro que el

${ }^{22}$ En la actualidad, el artículo 1 sobre suspensión de los lanzamientos sobre viviendas habituales de colectivos especialmente vulnerables sustituye el anterior plazo de dos años requerido por la Ley 1/2013, de 14 de mayo por el de cuatro desde la entrada en vigor de la Ley, para poder proceder al lanzamiento de las personas que se encuentren en condiciones de especial vulnerabilidad en las condiciones y con los requisitos que se detallan en el mismo. En relación con el indicado art. 1.1 de la Ley 1/2013, de 14 de mayo, señala Álvaro NúÑEZ IGLESIAS, (cfr. «La suspensión de los lanzamientos en la ejecución hipotecaria» en La protección del deudor hipotecario... 207) que la expresada medida por su carácter expropiatorio y sin que medie procedimiento ni indemnización, fue calificada en su día como contraria al art. 33. $3 \mathrm{CE}$, y objeto de recurso de inconstitucionalidad. Añade además, que esta medida protectora del artículo 1, que no se ha visto afectado en este punto por las reformas ulteriores del 2015, es muy restrictiva y así, por ejemplo, sólo afecta a los procesos de ejecución hipotecaria judicial o extrajudicial. Quedan fuera, por tanto -y aunque el bien afectado sea la vivienda habitual- los procesos de desahucio arrendaticio (por falta de pago de la renta, por ejemplo) o por precario. Y añade el A. que el legislador de mayo de 2013 (con referencia a la fecha de aprobación de esta disposición, aunque sus consideraciones son igualmente aplicables en la actualidad) debería haber arbitrado un sistema de ayudas al inquilinato, en los mismos supuestos de vulnerabilidad que tiene en cuenta para proteger al deudor hipotecario.

${ }_{23}$ Así se establece en el en el artículo 1 de la Ley 1/2013, de 14 de mayo, que ha mantenido en este extremo su redacción inicial.

${ }^{24}$ Esta circunstancia que se ha mantenido en la regulación vigente, ya fue criticada en su día por Álvaro NúÑEZ IGLESIAS, «La suspensión de los lanzamientos en la ejecución hipotecaria» en La protección del deudor hipotecario..., 203. 
precario por cuanto que la situación del deudor «no lanzado» está en la órbita de un precario de origen contractual, consentido por el propietario. Y en definitiva, el precario consentido de origen contractual, no es otra cosa que el comodato $^{25}$. El artículo 2 de la Ley 1/2013, de 14 de mayo, determina los documentos que habrá de presentar el deudor junto con su solicitud de suspensión del lanzamiento para acreditar «las circunstancias a que se refiere la ley», a los que se añade la «declaración responsable» del deudor o deudores relativa al cumplimiento de los requisitos exigidos, para considerarse situado en el ámbito de aplicación de esta Ley.

2. Adentrándonos algo más en el examen de la Ley $1 / 2013$, de 14 de mayo, podría señalarse que a la vista de las reformas que opera en la $\mathrm{LH}$, la Ley de Regulación del Mercado Hipotecario y la LEC, es posible afirmar que la expresada disposición da entrada a la intervención pública, tanto preventiva y judicial, propias del Derecho de Consumo, en la contratación del préstamo y crédito hipotecarios, limitando previamente lo que se puede pactar, permitiendo en algunas condiciones que el deudor se desvincule de lo estrictamente pactado y admitiendo la paralización de las ejecuciones o la alteración de sus términos ${ }^{26}$. La Ley $1 / 2013$, de 14 de mayo se aplica a todos los deudores hipotecarios, es decir, no sólo a los deudores hipotecarios sin recursos, como ocurría con el RD-ley 6/2012, de 9 de marzo, sino también a clientes de todo tipo de prestamistas (bancarios y no bancarios) ${ }^{27}$. Y entre las nuevas reglas que estatuye, la Disposición Adicional Tercera ordena al Banco de España la publicación de la Guía de Acceso al Préstamo Hipotecario, la cual fue publicada en efecto, en la web del Banco de España con fecha de 15 de julio de 2013 y que se incluye en la «fase de comercialización» que es la fase previa a la de contratación ${ }^{28}$. En el artículo 6 de la Ley 1/2013, bajo

${ }^{25}$ Compartimos aquí la opinión mantenida por Álvaro NúÑEZ IGLESIAS, «La suspensión de los lanzamientos en la ejecución hipotecaria» en La protección del deudor hipotecario..., 206.

${ }^{26}$ Cfr. M. ${ }^{a}$ B. SÁinz CANTero Caparrós, «La evolución de la posición del deudor hipotecario...», 7 ss. Por remisión entre otras disposiciones de la Ley 2/2009, de 31 de marzo, por la que se regula la contratación con los consumidores de préstamos o créditos hipotecarios y de servicios de intermediación para la celebración de contratos de comercialización, hemos de entender que la protección del deudor hipotecario no se limita tan solo a la que depara la normativa específica, sino que queda asimismo amparado dicho deudor por la normativa dirigida a la protección de los intereses de los consumidores en general (Real Decreto Legislativo 1/2007, de 16 de noviembre por el que se aprueba la LGDCU y otras leyes complementarias y la Ley 3/1991, de 10 de enero de competencia desleal).

${ }^{27}$ Cfr. M. ${ }^{\text {a }}$ DEl Mar Gómez LozAno, «La protección del consumidor en la comercialización de préstamos hipotecarios» en La protección del deudor hipotecario..., 179 ss.

${ }_{28} \mathrm{Vid} .<$ http://www.bde.es/bde/es/secciones/informes/Folletos/guia_de_acceso_a>. Con anterioridad a la publicación de la Directiva 2014/17/UE del Parlamento Europēo y 
el título de «Fortalecimiento de la protección del deudor hipotecario en la comercialización de los préstamos hipotecarios» se contempla como nueva medida de protección la denominada «expresión manuscrita» al establecer en su párrafo 1: En la contratación de préstamos hipotecarios a los que se refiere el apartado siguiente se exigirá que la escritura pública incluya, junto a la firma del cliente, una expresión manuscrita, en los términos que determine el Banco de España, por la que el prestatario manifieste que ha sido adecuadamente advertido de los posibles riesgos derivados del contrato ${ }^{29} \gg$.

del Consejo, de 4 de febrero de 2014, sobre los contratos de crédito celebrados con los consumidores para bienes inmuebles de uso residencial, se contemplaba una diferente protección y normativa aplicable al consumidor, según fuese o no cliente bancario. La Directiva mencionada en cambio, pretende garantizar que todos los consumidores sin distinción que concluyan contratos relativos a créditos al consumo que estén garantizados mediante hipoteca u otro tipo de garantía, en relación con bienes inmuebles de uso residencial, disfruten de un elevado grado de protección. Dado que la transposición a la normativa nacional de la indicada Directiva no es exigible hasta el 21/3/2016, y no se ha llevado a cabo todavía, se mantiene la legislación protectora del consumidor vigente en la actualidad, en tanto no se efectúen las debidas adaptaciones.

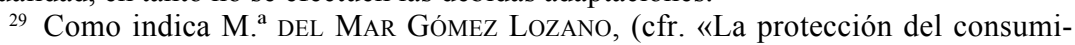
dor...», en La protección del deudor hipotecario..., 189), comentando este párrafo con el siguiente del mismo artículo 6, en relación con el aspecto subjetivo, la norma se aplica a los contratos que se suscriban con un prestatario persona física (quedando por tanto excluidas las personas jurídicas). $\mathrm{Y}$ en lo referente al ámbito objetivo la norma se aplica: $\left.1 .^{\circ}\right)$ a aquellos contratos en los que la hipoteca recaiga sobre una vivienda o cuya finalidad sea adquirir o conservar derechos de propiedad sobre terrenos o edificios construidos o por construir, y $2 .^{\circ}$ ) a aquellos contratos en los que concurra alguna de las siguientes circunstancias: a) que se estipulen limitaciones a la variabilidad del tipo de interés, del tipo de las cláusulas suelo y techo, en los cuales el límite de variabilidad a la baja sea inferior al límite de variabilidad al alza; b) que lleven asociada la contratación de un instrumento de cobertura del riesgo de tipo de interés, o bien; c) que se concedan en una o varias divisas. Estos mismos términos han sido incluidos y desarrollados en el anejo IX de la Guía de Acceso al Préstamo Hipotecario, publicada en la web del Banco de España, como anteriormente indicamos el 15 de julio de 2013, pero en opinión de la A. ni las medidas adoptadas en la Ley 1/ 2013 en lo referente a esta fase de comercialización, ni tampoco las contempladas en la Guía de Acceso permiten asegurar que el consumidor conozca realmente todos los extremos del producto financiero que contrata y de los riesgos que conlleva y que en definitiva quede protegido conforme a lo preceptuado en el artículo 51.1 de la Constitución española. En relación a la indicada prevención se muestra escéptico I. SERRANO GARCÍA (cfr. «El drama social de los desahucios: soluciones en Derecho español», en Le obbligazioni e i contratti nel tempo della crisi económica. Italia e Spagna a confronto [a cura di Giuseppe Grisi] (Napoli: Jovene Editore, 2014), 168) quien estima que le hubiera satisfecho más -si es que se estimase que hacía falta- que los Notarios advirtieran a los firmantes del préstamo garantizado con la hipoteca, de las consecuencias - derivadas de las variaciones del mercado- de las cláusulas que firmaban. $\mathrm{O}$ bien que los Registradores se negaran a inscribir aquellas hipotecas que garantizasen préstamos en los que hubie- 
3. En materia de regulación del mercado hipotecario, el artículo 4 de la Ley 1/2013 confiere una nueva redacción al párrafo segundo del artículo quinto de la Ley de Regulación del Mercado Hipotecario (LRMH) 2/1981, de 25 de marzo, que queda redactado del siguiente modo: «El préstamo o crédito garantizado con esta hipoteca no podrá exceder del 60 por ciento del valor de tasación del bien hipotecado. Cuando se financie la construcción, rehabilitación o adquisición de viviendas, el préstamo o crédito podrá alcanzar el 80 por ciento del valor de tasación, sin perjuicio de las excepciones que prevé esta Ley. El plazo de amortización del préstamo o crédito garantizado, cuando financie la adquisición, construcción o rehabilitación de la vivienda habitual, no podrá exceder de treinta años ${ }^{30} \gg$. La Ley 1/2013 introduce además controles importantes en las sociedades de tasación y sus servicios, añadiéndose nuevos requisitos formales que pretenden garantizar la información para el que se adeuda sobre las condiciones que habrá de asumir. En efecto, el artículo 3 de la LRMH (Ley 2/1981, de 25 de marzo) resulta asimismo modificado por la Ley $1 / 2013$, con la pretensión de que las entidades de tasación sean independientes de los Bancos que conceden el préstamo y que por tanto no puedan superar de forma directa o indirecta, el 10 por ciento del capital o de los derechos de la entidad.

4. Por virtud de la Ley $1 / 2013$, complementada por la Ley 8/2013, de 26 de junio, de rehabilitación, regeneración y renovación urbanas, se verifica asimismo una reforma trascendental en materia de ejecución ordinaria e hipotecaria $^{31}$. Podemos destacar por su importancia las siguientes disposicio-

ra cláusulas sospechosas de haber sido predispuestas por la Entidad bancaria prestamista. La postura que está a juicio del A. prevaleciendo aquí equivocadamente, es la de que el control se haga exclusivamente por el poder judicial, sin considerar la función preventiva que cumplen Notarios y Registradores, consistente en un buen funcionamiento del Registro de Condiciones Generales de Contratación, y que sería muy beneficiosa para los consumidores.

${ }^{30} \mathrm{El}$ hecho de que el destino del inmueble adquirido modifique el régimen financiero del préstamo en los términos que acabamos de examinar, puede provocar que el préstamo con garantía hipotecaria para la adquisición de la vivienda habitual se restrinja y encarezca en comparación con el préstamo hipotecario normal, pudiendo cuestionarse asimismo si serán aplicables las normas protectoras al comprador del inmueble que $n{ }^{\circ}{ }^{2}$ declaró el uso como vivienda habitual en la escritura, por cuanto que el reformado $21.3 \mathrm{LH}$ por virtud de la Ley 1/2013, de 14 de mayo, establece la obligación de declarar el uso pretendido, pero sin mencionar las consecuencias de una declaración falsa o incorrecta (Cfr. M. EsPEJO LERDO DE TEJADA, «Contenido financiero del préstamo y protección del deudor hipotecario, Primera aproximación a su tratamiento en la Ley 1/2013, de 14 de mayo, de medidas para reforzar la protección a los deudores..., hipotecarios, reestructuración de deuda, y alquiler social», en La protección del deudor hipotecario..., 49.

${ }^{31}$ Cfr. Carmen SenÉs Montilla, «La reforma de la ejecución ordinaria e hipotecaria (Ley 1/2013, de 14 de mayo de medidas para reforzar la protección a los deudores hipote- 
nes que inciden o bien en la delimitación del volumen de responsabilidad exigible en el proceso de ejecución, o bien determinan los sujetos pasivamente legitimados para soportar la actividad ejecutiva:

a) Establecimiento de un límite legal a los intereses de demora de préstamos o créditos para la adquisición de vivienda habitual, garantizados con hipotecas constituidas sobre la misma vivienda. Con relación a los préstamos para la adquisición de la vivienda habitual ${ }^{32}$, el actual apartado 3 del artículo $114 \mathrm{LH}$, introducido por la precitada Ley $1 / 2013$, ha quedado redactado con una formulación netamente imperativa en lo referente a la cuantía de los intereses moratorios, que en cumplimiento de lo ordenado en la EM de la referida Ley, no podrán ser superiores a tres veces el interés legal del dinero, y con exclusión expresa tanto del anatocismo, como de la capitalización de los intereses vencidos, con las muy circunscritas excepciones contempladas en la LEC $^{33}$. Hemos de tener asimismo en cuenta que en determinados casos, concretamente los préstamos de fecha anterior al 10 de marzo de 2012, fecha de entrada en vigor del Real Decreto-ley 6/2012 de 9 de marzo, existe un doble límite para los intereses de demora: el reconocido en el artículo 4 del RDL (que es el resultante de sumar a los intereses remuneratorios pactados en el préstamo un $2 \%$ - sobre el capital pendiente de préstamo) y el del artículo $114.3 \mathrm{LH}$ al que nos acabamos de referir ${ }^{34}$. Se destaca asimismo por la doctrina que la DT

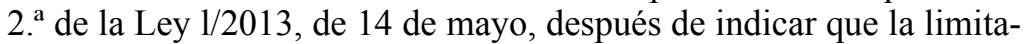
ción de los intereses de demora de hipotecas constituidas sobre la vivienda habitual, será de aplicación a las hipotecas constituidas con posterioridad a la entrada en vigor de la Ley, establece, sin embargo, una retroactividad de tipo medio por cuanto que el nuevo criterio legal

carios, reestructuración de deuda y alquiler social)» en La protección del deudor hipotecario..., 149 ss.

${ }^{32}$ Cfr. M. Espejo LeRdo DE TeJadA, «Contenido financiero del préstamo y protección del deudor hipotecario...», 36-54.

${ }_{33}$ El apartado 3 del artículo 114 LH dispone: «Los intereses de demora de préstamos o créditos para la adquisición de vivienda habitual, garantizados con hipotecas constituidas sobre la misma vivienda, no podrán ser superiores a tres veces el interés legal del dinero y sólo podrán devengarse sobre el principal pendiente de pago. Dichos intereses de demora no podrán ser capitalizados en ningún caso, salvo en el supuesto previsto en el artículo 579.2.a) de la Ley de Enjuiciamiento Civil».

${ }^{34}$ Sobre este particular ESPEJO LERDO DE TEJADA (cfr. «Contenido financiero del préstamo y protección del deudor hipotecario...», 44-45) cuya opinión suscribimos, estima que en la filosofía protectora de la Ley debería aplicarse en cada supuesto concreto el tipo que resulte más reducido o beneficioso para el deudor. 
termina por aplicarse a las siguientes situaciones: a los intereses devengados con posterioridad a la entrada en vigor de la Ley; a los generados antes de la entrada en vigor de la Ley que no hubiesen sido satisfechos y a los ya reclamados judicialmente en procedimientos no concluidos a la entrada en vigor de la Ley $^{35}$.

b) Modificación del límite legal aplicable a los intereses moratorios derivados de los préstamos o créditos garantizados con hipoteca sobre la vivienda habitual del deudor que se encuentre en el umbral de exclusión que define el Real Decreto- ley 6/2012, de 9 de marzo; límite que pasa del 2,5 en el 2012 al $2 \%$ en el 2013 (artículo 4. 1 RDL 6/2012 en su redacción dada por Ley 1/2013, de 14 de mayo) ${ }^{36}$.

${ }^{35}$ Cfr. Espejo LeRdo de TejadA, «Contenido financiero del préstamo y protección del deudor hipotecario...». Juan Ignacio NAVAS (cfr. «La protección del hipotecado pendiente de Luxemburgo», Diario La Ley 8593 (Sección Tribuna, 30 de Julio de 2015)) destaca además el planteamiento que se hace el Juzgado de 1. ${ }^{\mathrm{a}}$ instancia e Instrucción núm. 2 de Marchena el cual se pregunta respecto de qué ocurre con aquellos consumidores previos a la entrada en vigor de la Ley 1/2013. ¿Pueden declararse nulos y no exigibles los intereses abusivos pagados con anterioridad?, ¿quedan o no protegidos por la normativa nacional? En su opinión, la conclusión es clara: la primacía del derecho comunitario hace que la protección de la directiva sobre el consumidor esté vigente desde su promulgación, el 5 de abril de 1993. Parece evidente que si ha existido abuso y desequilibrio por la aplicación de un contrato de adhesión, esa cláusula se debe tener por no puesta y considerada nula antes y después de la Ley $1 / 2013$, ya que la Directiva 13 de Consumo, que establece el equilibrio en la contratación con los consumidores, es del año 1993.

${ }^{36}$ El TS sigue manteniendo con frecuencia que los intereses moratorios no resultan controlables mediante la legislación represora de la usura, así por ejemplo en STS de 26/10/2011, no así en cambio en STS de 7/5/2002. La nueva sensibilidad social hacia los deudores sin recursos, la presión que la misma pueda ejercer sobre los tribunales de justicia y la propia diversidad de soluciones jurisprudenciales, quizá hubieran justificado una intervención legislativa de mayor calado, y más clarificadora en toda esta materia (cfr. también en relación a esta temática María GoÑI RodRÍGUEZ DE ALMEIDA («Las consecuencias de la existencia de una cláusula abusiva en el contrato de préstamo hipotecario: especial referencia a los intereses moratorios», Revista Crítica de Derecho Inmobiliario, año XCI, Núm. 749 (Mayo-Junio 2015), 1565 ss.) quien estima que, ante los dos efectos que se ofrecen como posibles cuando exista una cláusula con intereses moratorios abusivos tenerla por no puesta, o declarar nulo todo el contrato- ha de optarse por el primero de ellos, tal y como aboga el Consejo General del Poder Judicial, y parece más razonable por el propio carácter de estos intereses. La jurisprudencia española ha seguido en general este criterio: así, por ejemplo, el AAP Castellón de 18 de diciembre de 2013, según el cual no cabe integración o moderación de los intereses, posibilidad ésta prevista en la Disposición transitoria segunda de la Ley 1/2013 y que parece contravenir el Derecho comunitario. Sin embargo, de otras dos resoluciones de los Tribunales (SAP Córdoba 20 de junio de 2014, SAP Alicante 11 de septiembre de 2014), parece deducirse que cabe la moderación o rebaja de los intereses moratorios hasta el máximo legalmente permitido, cuando estos sean abusivos. También la STJUE de 21 de enero de 2015 vuelve a poner de manifiesto la po- 
c) Posibilidad de reclamación de la totalidad de lo adeudado por capital y por intereses si se hubiese convenido el vencimiento total en caso de falta de pago de, al menos, tres plazos mensuales sin cumplir el deudor su obligación de pago o un número de cuotas tal que suponga que el deudor ha incumplido su obligación por un plazo, al menos, equivalente a tres meses, y este convenio constase en la escritura de constitución y en el asiento respectivo ${ }^{37}$.

d) Establecimiento asimismo de que las medidas previstas en el Real Decreto-ley 6/2012 se aplicarán igualmente a los fiadores y avalistas hipotecarios del deudor principal, respecto de su vivienda habitual y con las mismas condiciones que las establecidas para el deudor hipotecario (artículo 2 del Real Decreto-ley 6/2012 redactado por el apartado uno de la disposición final decimocuarta de la Ley 8/2013, de 26 de junio).

e) El Artículo 3 bis del Real Decreto-ley 6/2012 redactado por el apartado dos de la disposición final decimocuarta de la Ley 8/2013, de 26 de junio, sanciona el reconocimiento a los fiadores, avalistas e hipotecantes $n .{ }^{\circ}$ deudores que se encuentren en el umbral de exclusión de la posibilidad de exigir que la entidad agote el patrimonio del deudor principal, sin perjuicio de la aplicación a éste, en su caso, de las medidas previstas en el Código de Buenas Prácticas, antes de reclamarles

sibilidad o la facultad del juez de integrar el contrato y moderar la cláusula que contemple intereses moratorios abusivos en un préstamo hipotecario.

37 Así se establece en el actual 693.2 LEC nuevamente redactado por Ley 19/2015, de 13 de julio, de medidas de reforma administrativa en el ámbito de la Administración de Justicia y del Registro Civil. En relación al indicado precepto que coincide literalmente en el extremo relativo al vencimiento anticipado de la deuda en cuanto a capital en intereses, salvo en el último inciso concerniente al «asiento respectivo», con el artículo precedente redactado por la Ley 1/2013, de 14 de mayo, indicó en su momento M. ESPEJO LERDO DE TEJADA (cfr., «Contenido financiero del préstamo y protección del deudor hipotecario...», 51) que la ubicación sistemática de la norma permite afirmar que no atañe en exclusiva al vencimiento anticipado en caso de préstamo hipotecario destinado a la adquisición de la vivienda habitual. Cfr. también Juan Ignacio NAVAS, «La protección del hipotecado pendiente de Luxemburgo...», quien destaca que el juzgado de 1. ${ }^{\mathrm{a}}$ instancia de Miranda de Ebro cuestionó el 24 de febrero de 2014 si lo establecido en la normativa española de que tres impagos de cuotas son suficientes para ejecutar es conforme a la normativa comunitaria «sin tener en cuenta otros factores como la duración o la cuantía del préstamo o cualesquiera otras causas concurrentes relevantes». En el «caso Aziz», Luxemburgo resolvió el 14 de marzo de 2013 que la ejecución debía ser equilibrada evitando la abusividad. Y en consonancia con la misma, podríamos estimar que la legislación que permite la ejecución hipotecaria tras tres impagos, sin tomar en consideración ninguna circunstancia concurrente, sigue vigente generando inseguridad jurídica. 
la deuda garantizada, aun cuando en el contrato hubieran renunciado expresamente al beneficio de excusión ${ }^{38}$.

f) Podemos asimismo citar entre otras medidas introducidas por la Ley $8 / 2013$, de 26 de junio, la consideración como nueva causa de oposición a la ejecución del carácter abusivo de una cláusula contractual. En efecto, en el marco de las disposiciones generales de la ejecución forzosa se introduce el control de oficio de las cláusulas abusivas, que el juez podrá apreciar al tiempo del despacho de la ejecución (art. 552. 1 II LEC). En este sentido, el actual párrafo segundo del número 1 del artículo 552 LEC dispone que "cuando el tribunal apreciare que alguna de las cláusulas incluidas en un título ejecutivo de los citados en el artículo 557.1 pueda ser calificada como abusiva, dará audiencia por quince días a las partes. Oídas éstas, acordará lo procedente en el plazo de cinco días hábiles conforme a lo previsto en el artículo 561.1.3. ${ }^{\mathrm{a} 39} \gg$. Y por su parte el actual artículo 561.1.3. ${ }^{\mathrm{a}}$ LEC establece: "Cuando se apreciase el carácter abusivo de una o varias cláusulas, el auto que se dicte determinará las consecuencias de tal carácter, decretando bien la improcedencia de la ejecución, bien despachando la misma sin aplicación de aquéllas consideradas abusi$\operatorname{vas}^{40} . »$ Esta previsión se incorpora atendiendo a la sentencia del

${ }^{38}$ Tanto el artículo 2 como el 3 bis del Real Decreto-ley 6/2012 mantienen su redacción dada por virtud de la Ley 8/2013, de 26 de junio.

39 En efecto, la apreciación judicial de que una cláusula contractual pueda ser abusiva comporta la necesidad de conferir un trámite de audiencia a las partes, al ser ésta una exigencia elemental del principio de contradicción. Precisamente en este sentido se ha manifestado el Tribunal de Justicia de la Unión Europea (STUE, Sala Primera, de 21 de febrero de 2013).

${ }^{40}$ En efecto, el art. 552.1 LEC alude simplemente a la circunstancia de que el tribunal apreciare que alguna de las cláusulas incluidas en un título ejecutivo pudiese ser calificada como abusiva, sin mayor concreción, pronunciándose asimismo en términos muy genéricos el art. 561.1.3. ${ }^{\mathrm{a}}$, al que se remite aquel precepto; pero en cambio, el art. 695.1.4. . ${ }^{2}$ í que precisa que «sólo se admitirá la oposición del ejecutado cuando se funde en las siguientes causas:... 4. ${ }^{a}$ El carácter abusivo de una cláusula contractual que constituya el fundamento de la ejecución o que hubiese determinado la cantidad exigible». Sobre este particular, indica Manuel Almenar Belenguer (cfr. «Cuestiones de actualidad sobre la ejecución hipotecaria judicial (El procedimiento de ejecución hipotecaria a la luz de la doctrina del TJUE y de las últimas reformas legales)», en Varia Studia, Libro-homenaje al profesor Doctor Luis Rodríguez Ennes (Pontevedra: Patronato del Instituto de Estudios Ibéricos, 2015), 74-76) que «el equilibrio entre el derecho de defensa y el nivel de protección del consumidor que pretende garantizar la Directiva (93/13), de un lado, y las singulares características del procedimiento, de otro lado, unido a la posibilidad de apreciar el carácter abusivo de una cláusula en cualquier momento y, desde luego, tan pronto como se pretenda «actuar» la cláusula o, en su caso, plantear la cuestión en un procedimiento declarativo 
Tribunal de Justicia de la Unión Europea de 14 de marzo de 2013, que resuelve la cuestión prejudicial planteada por el Juzgado de lo Mercantil n. ${ }^{\circ} 3$ de Barcelona respecto de la incidencia en la legislación hipotecaria española de la Directiva 93/13/CEE del Consejo, de 5 de abril de $1993^{41}$. En todo caso, es claro que el juez nacional, como juez

con cognición plena, permite afirmar, primero, que el juez ha de centrar su supervisión en las cláusulas efectivamente aplicadas por el ejecutante y relativas al fundamento de la ejecución o a la determinación de la cantidad exigible, y, segundo, que tanto la expresión «fundamento de la ejecución» como «determinación de la cantidad exigible» han de ser objeto dc una interpretación amplia, de manera que comprendan toda cláusula que incida, directa o indirectamente, de modo principal o accesorio, en uno u otro conceptos». Añade asimismo el autor (loc. cit.) a nuestro juicio muy acertadamente, con referencia a la decisión del juez que contempla el art. 561.1.3. . LEC, que en términos generales, la improcedencia de la ejecución procederá cuando estemos ante una causa que constituya el fundamento de la ejecución (v.gr. vencimiento anticipado); mientras que la inaplicación de las cláusulas abusivas tendrá lugar cuando se trate de cláusulas relativas a la determinación de la cantidad exigible (intereses remuneratorios, intereses de demora, reclamación de gastos o comisiones, conversión de divisas...), aunque en este último caso pueden darse diversas situaciones que detalla el A., en función de la cláusula de que se trate.

${ }^{41}$ Cfr. supra nota 21. Con esta Sentencia quedó claro que en nuestro procedimiento hipotecario, el juez ya no puede limitarse a realizar un análisis formal del título ejecutivo, sino que tiene la función de proteger al consumidor y sus intereses; y por ello vigilar el equilibrio contractual en la contratación. Podríamos destacar a este respecto las Conclusiones de la Jornada sobre las repercusiones de la doctrina del TJUE en materia de cláusulas abusivas en ejecuciones hipotecarias de 8 de mayo de 2013, que recoge criterios orientativos para valorar el carácter abusivo de una cláusula contractual, las consecuencias de la declaración de una cláusula como abusiva y las facultades del juez para actuar de oficio en materia de cláusulas abusivas. En:

http://www. poderjudicial.es/cgpj/es/Poder_Judicial/Tribunales_Superiores_de_Justicia/TSJ_Cataluna.

Sobre la necesidad y formas de control vid. Jacinto José PÉREZ BENíTEZ, «El control judicial de las condiciones generales de la contratación y de las cláusulas abusivas. Tutela procesal de los intereses de grupo», en I Foro de encuentro de jueces y profesores de Derecho mercantil, coord. por J. R. Salelles Climent, M. J. Guerrero Lebrón, R. Fuentes Devesa (Valencia: Tirant lo Blanch, 2010), 161-218. Y sobre la posibilidad de articular el control de las cláusulas en la oposición a la ejecución hipotecaria vid. A. CARRASCO PERERA, La Ley 1/2013, de 14 de mayo, de reforma hipotecaria y la articulación procesal del control sobre cláusulas abusivas en la ejecución hipotecaria, CESCO, <http: //www. uclm.es/centro/cesco/>. Recordemos que según el artículo 82 del Real Decreto legislativo $1 / 2007$, de 16 de noviembre 1 . Se considerarán cláusulas abusivas todas aquellas estipulaciones no negociadas individualmente y todas aquéllas prácticas no consentidas expresamente que, en contra de las exigencias de la buena fe causen, en perjuicio del consumidor y usuario, un desequilibrio importante de los derechos y obligaciones de las partes que se deriven del contrato. Y que también la Directiva 93/13/CEE afirma en el artículo 3.1 lo siguiente: «Las cláusulas contractuales que no se hayan negociado individualmente se considerarán abusivas si, pese a las exigencias de la buena fe, causan en detrimento del 
comunitario, podría paralizar la ejecución para plantear cuestión prejudicial al Tribunal de Justicia de la Unión Europea al amparo del artículo 43 LEC, aunque también podría plantearse en el curso de la ejecución ordinaria posterior a la adjudicación del bien inmueble ${ }^{42}$. En la actualidad, todos los ordenamientos europeos arbitran instrumentos para garantizar el equilibrio de las partes en el momento de la contratación y en el cumplimiento del contrato, atendiendo a la buena fe y equidad, tales como la cláusula rebus sic stantibus que ampara la revisión y la resolución contractual en caso de alteración extraordinaria de circunstancias $^{43}$. Sin embargo, la Ley $1 / 2013$, de 14 de mayo no introduce de un modo decidido el control del equilibrio contractual funcional en la ejecución hipotecaria y se limita a dar entrada al control del desequilibrio contractual inicial, producido por las cláusulas abusivas pactadas, sin considerar el que puede generar la aplicación de una norma ${ }^{44}$. Con relación a esta particular temática concerniente a las cláusulas abusivas, si tomamos en consideración que las CGC se caracterizan por no ser el resultado de un pacto sino de la imposición del prestamista -en la práctica totalidad de los casos, entidades de crédito- resulta imprescindible asegurarse de que su contenido no

consumidor un desequilibrio importante entre los derechos y obligaciones de las partes que se derivan del contrato». Así pues, y aquí nos adherimos a la opinión de M. ${ }^{a}$ B. SÁINZ CANTERo CAPARRós, (cfr. «La evolución de la posición del deudor hipotecario...», 26), «si de lo que se trata es de garantizar el equilibrio contractual y la defensa del deudor consumidor, el control judicial debe extenderse a todas las fases del contrato: desde la información pre-contractual, a la contratación y sus efectos».

${ }^{42}$ Cfr.. M. ${ }^{a}$ B. SÁinz CANTERo CAPARrós, «La evolución de la posición del deudor hipotecario...», 27.

${ }^{43}$ El Derecho contractual uniforme-los Principios Unidroit 2010, los PECL (Principios de Derecho Europeo de Contratos), el Proyecto de Marco Común de Referencia (DCFR) y la Propuesta del Reglamento del Parlamento Europeo y del Consejo relativa a una normativa común de Compraventa europea, de 11 de octubre de 2011 (Propuesta CESL), han venido a consagrar también la imprescindible intervención judicial, ya sea sobre la formación del contrato, como sobre los términos de su ejecución, en aras de la justicia contractual. Véase al respecto Francisco J. ANDRÉs SANTOS, «Procedimientos relativos al sobreendeudamiento de particulares en el Derecho europeo» en La protección del deudor hipotecario..., 125 ss.

${ }^{44}$ Cfr. M. ${ }^{a}$ B. SÁInz CANTERo CAPARrós, «La evolución de la posición del deudor hipotecario...», 35. Cfr. también en relación a este particular, Lourdes BlANCO PÉREZ RUBIO, «El control específico sobre el contenido de los clausulados negociales», Revista Crítica de Derecho Inmobiliario 749, Año XCI (Mayo-Junio 2015), trabajo que tiene por objeto realizar un profundo estudio del control específico sobre el contenido de las cláusulas que no han sido objeto de negociación individual y que causan al consumidor un perjuicio importante por tratarse de cláusulas abusivas. 
suponga un desequilibrio en perjuicio del adherente (esto es el prestatario). Y cabe la posibilidad de que nos cuestionemos cómo después de haberse dictado la mencionada sentencia de 14 de marzo de 2013 del TSJUE, por la que se modifica procesalmente la forma de identificar las CGC abusivas, así como los criterios para determinar cuáles han de entenderse por tales, no se haya realizado hasta el día de hoy reforma alguna en profundidad, para evitar la entrada en el mercado de nuevas CGC con contenidos contrarios a Derecho ${ }^{45}$.

Respecto de los recursos procedentes contra el auto que declare el carácter abusivo de la cláusula, hasta ahora, y con anterioridad a la reforma llevada a cabo por virtud de la Ley 9/2015 de 25 de mayo de medidas urgentes en materia concursal, el artículo 695 LEC vetaba al ejecutado la posibilidad de recurrir en apelación el auto desestimatorio

${ }^{45}$ La doctrina de la DGRN contraria a reconocer el papel activo del Registrador en el ámbito de la calificación del contenido $\mathrm{y}$, en definitiva, del control de legalidad de las CGC, ha ido enmendándose progresivamente en favor del consumidor, pudiendo citarse en este sentido, la RDGRN de 11 de enero de 2011. La LCGC de 1998 prevé un control de legalidad de las CGC, que se centra en dos aspectos: por una parte, en la oportuna resolución judicial para el caso de que el adherente en la creencia de que una CGC fuese contraria a Derecho o abusiva interpusiese el correspondiente pleito; y por otra parte, el control preventivo de legalidad de las CGC se basa en la creación del RCGC, registro de carácter público, cuya gestión se encarga a los registradores de la propiedad. (cfr. Iñigo Mateo y Villa, «Cláusulas abusivas e inscripción registral» en La protección del deudor hipotecario..., 71 quien entiende que el legislador debe centrarse prioritariamente en la justicia preventiva, de suerte que el registrador encargado del RCGC pueda calificar, esto es emitir un juicio independiente sobre la legalidad de las CGC antes de que éstas sean utilizadas y entren en el mercado. El Consejo General del Notariado en uso de sus competencias, en el pleno del día 27 de Abril de 2013, aprobó «la constitución del Órgano de Control de las Cláusulas Abusivas (OCCA), cuya gestión corresponde a la Comisión de Consumidores del Consejo. Es un órgano que actúa de forma preventiva, y cuya finalidad es evitar que se introduzcan cláusulas abusivas en los contratos con condiciones generales de la contratación celebrados entre empresarios o profesionales y consumidores. En el mismo sentido Pedro Luis SERRERA Contreras (cfr. "Algunas reflexiones en torno a la Ley de Protecci6n de Deudores Hipotecarios», Revista Crítica de Derecho Inmobiliario 747, año XCI (Enero-Febrero 2015), 191 ss.) propone la medida preventiva consistente en que se impida el acceso al Registro de las cláusulas abusivas o ilegales mediante el establecimiento de cuáles sean las mismas. Bastaría para ello una referencia general en el artículo 12 de la LH, mientras que la enumeración concreta de tales cláusulas podría incluirse en el artículo 51.6 del Reglamento hipotecario; o bien que la enumeración de cláusulas no inscribibles con la hipoteca se incluyera en el propio artículo 12 de la LH debidamente modificado y desarrollado, completándose esa redacción del nuevo artículo 12 de la LH con una habilitación al Gobierno para que anualmente pudiera retocar esa lista de cláusulas abusivas y así adecuar la enumeración a las necesidades sentidas y a las circunstancias de la sociedad. 
de la oposición basada en la existencia de una cláusula contractual abusiva $^{46}$.

g) Dos son las medidas que se disponen en la ejecución ordinaria que sigue a la ejecución hipotecaria sobre vivienda habitual del deudor en el artículo 579 LEC, después de su redacción dada por la Ley $1 / 2013$, de 14 de mayo, y que se ha mantenido subsistente: por una parte, la exoneración parcial de la deuda no satisfecha con la realización de la garantía hipotecaria, en los términos, condiciones y plazos, que se definen en la letra a) del apartado 2 del artículo 579 de la LEC; y, por otra, la participación del deudor en la enajenación de la vivienda efectuada por el rematante o adjudicatario en los diez años siguientes a la aprobación del remate o la adjudicación, mediante la condonación parcial de la deuda pendiente al tiempo de la enajenación, en un $50 \%$ neto de la plusvalía obtenida por el ejecutante o cesionario (letra b) del apartado 2 del artículo 579 de la LEC) ${ }^{47}$.

h) Tras de la Ley 1/2013, de 14 de mayo, se adiciona el apartado 3 al artículo 654 LEC, que en la actualidad dispone: «En el caso de que la ejecución resultase insuficiente para saldar toda la cantidad por la que se hubiera despachado ejecución más los intereses y costas devengados durante la ejecución, dicha cantidad se imputará por el siguiente orden: intereses remuneratorios, principal, intereses moratorios y costas».

i) Podemos citar como medidas de incentivación para la participación de los postores en la celebración de la subasta, introducidas por virtud de la Ley $1 / 2013$, de 14 de mayo y en las que incidiría con posterioridad la la Ley 19/2015, de 13 de julio las siguientes:

1) La minoración del depósito necesario para tomar parte en la subasta de bienes muebles, que pasa del 20 al $5 \%$ del valor de tasación de los bienes (art. 647.1.3. ${ }^{\circ} \mathrm{LEC}^{48}$ ).

${ }^{46}$ Después de la reforma del apartado 4 del artículo 695 LEC en virtud de la precitada Ley del 2015, como reiteraremos más adelante, se posibilita en cambio al deudor hipotecario interponer recurso de apelación contra el auto que desestime su oposición a la ejecución, si ésta se hubiera fundado en la existencia de una cláusula contractual abusiva».

${ }^{47}$ Muy juiciosamente estima Carmen SenÉs Montilla (cfr. La reforma de la ejecución ordinaria e hipotecaria..., 159) que la eficacia de las expresadas medidas para paliar la situación que atraviesan las familias es muy cuestionable y además encierra el contrasentido de favorecer al deudor que en plazos determinados puede satisfacer parte de la deuda, a costa de ser inflexible con el deudor que no puede afrontarla sin grave riesgo de exclusión social.

${ }^{48}$ Este depósito consistente en el 5 por ciento del valor de tasación de los bienes se ha mantenido tras de la reforma del artículo 647.1.3. ${ }^{\circ}$ LEC, por virtud de la Ley 19/2015, de 13 de julio, de medidas de reforma administrativa en el ámbito de la Administración de Justicia y del Registro Civil. Estimamos que toda medida que fomente la mayor participa- 
2) El mayor contenido del anuncio de la subasta que comprenderá los datos registrales y, en su caso, la referencia catastral del inmueble, la situación posesoria si le constare al juzgado y la indicación de la posibilidad de una consulta más detallada en el portal de subastas judiciales y electrónicas (artículo 668 LEC) ${ }^{49}$.

3) La ampliación del plazo para que el rematante haga efectiva la diferencia entre el depósito y el precio del remate, que pasa de veinte a cuarenta días (art. 670.1 $\mathrm{LEC}^{50}$ ).

j) Tras de la modificación del artículo 671 LEC por virtud de la Ley $1 / 2013$, de 14 de mayo se incardina por una parte en el articulado de la ley procesal el tratamiento diferenciado de la vivienda habitual en caso de subasta sin postor, y por otra, se eleva al $70 \%$ del valor de tasación, el importe por el que el ejecutante puede adjudicarse la vivienda habitual del ejecutado, salvo que la cantidad que se le deba por todos los conceptos sea inferior a dicho porcentaje, en cuyo caso la adjudicación podrá tener lugar por el $60 \%$ del valor de tasación ${ }^{51}$.

ción de postores en las subastas es buena, por lo que hay que elogiar la reducción del $20 \%$ del depósito necesario para pujar, sin que sea óbice para manifestar que tal vez debiera haberse eliminado la exigencia de depósito a los postores de las subastas lo que fomentaría una mejor adjudicación de los bienes subastados. Suscribimos aquí la opinión mantenida por Rosa Catena Real, «Las recientes reformas legislativas...», 4.

49 En el actual artículo 646 LEC en su redacción dada por virtud de la Ley 19/2015, de 13 de julio, de medidas de reforma administrativa en el ámbito de la Administración de Justicia y del Registro Civil, se ha ampliado aún más el contenido del anuncio de la subasta, que se publicará en el Boletín Oficial Estado» contendrá la fecha del mismo, la Oficina judicial ante la que se sigue el procedimiento de ejecución, su número de identificación y clase, así como la dirección electrónica que corresponda a la subasta en el Portal de Subastas. Además, según el Artículo 668 II LEC, también redactado por esta última disposición «En el Portal de Subastas se incorporará, de manera separada para cada una de ellas, el edicto que expresará, además de los datos indicados en el artículo 646, la identificación de la finca o fincas objeto de la subasta, sus datos registrales y la referencia catastral si la tuvieran, así como cuantos datos y circunstancias sean relevantes para la subasta y, necesariamente, el avalúo o valoración que sirve de tipo para la misma, la minoración de cargas preferentes, si las hubiera, y su situación posesoria, si consta en el procedimiento de ejecución»».

${ }^{50}$ Este precepto se ha mantenido subsistente tras de la reforma del artículo 670 LEC por virtud de la precitada Ley 19/2015, de 13 de julio. En relación al mismo indica Rosa Catena Real, «Las recientes reformas legislativas...», 4, que con esta medida se pretende evitar que la entidad bancaria se adjudique el bien subastado por un importe menor al $60 \%$ del valor por el que se tasó el inmueble, situación que se estaba dando con demasiada frecuencia, pues al quedar la subasta desierta el acreedor se adjudicaba el bien por un importe muy inferior al valor de tasación del inmueble.

${ }^{51}$ También este artículo ha conservado íntegramente su redacción tras de la publicación de la mencionada Ley 19/2015, de 13 de julio. 
k) La Ley 1/2013 daría una nueva redacción al artículo 129 LH $^{52}$. En el apartado 2 se establecen algunos de los requisitos y formalidades a los que se sujeta la venta extrajudicial del bien hipotecado. De la nueva regulación podemos destacar los aspectos siguientes:

k.1) La ley de reforma establece una doble limitación a la preceptiva fijación por los interesados del valor de tasación del bien hipotecado: a) El valor en que los interesados tasen la finca para que sirva de tipo en la subasta no podrá ser distinto del que, en su caso, se haya fijado para el procedimiento de ejecución judicial directa, ni podrá en ningún caso ser inferior al 75 por cien del valor señalado en la tasación que, en su caso, se hubiere realizado en virtud de lo previsto en la Ley 2/1981, de 25 de marzo, de regulación del mercado hipotecario (letra a) del apartado 2 del artículo 129 de la $\mathrm{LH})^{53}$.

k. 2) El artículo 129. 2 f) de la LH grava al Notario cuando éste considere que alguna de las cláusulas del préstamo hipotecario que constituya el fundamento de la venta extrajudicial o que hubiese determinado la cantidad exigible pudiera tener carácter abusivo, con la obligación de ponerlo en conocimiento del deudor, del acreedor y en su caso, del avalista e hipotecante n. ${ }^{\circ}$ deudor, a los efectos oportunos. En todo caso, el Notario suspenderá la venta extrajudicial cuando cualquiera de las partes acredite haber planteado ante el Juez que sea competente, conforme a lo establecido en el artículo 684 de la LEC, el carácter abusivo de dichas cláusulas contractuales. Conforme a este último precepto la competencia para conocer de la pretensión de anulación de la cláusula abusiva corresponderá al Juzgado de Primera Instancia del lugar donde radique la finca hipotecada (art. 684.1.1. ). La desestimación por el Juzgado de Primera Instancia del carácter abusivo de una cláusula que constituya el fundamento de la ejecución extrajudicial

${ }^{52}$ La letra a) del número 2 de este precepto aunque ha sido nuevamente redactada por virtud de la Ley 19/2015, de 13 de julio, coincide sustancial y casi literalmente con la redacción precedente dada en virtud de La Ley 1/2013.

53 Sobre este particular, indicaremos que estimamos desafortunado el límite mencionado por cuanto que ya existía una norma anterior, más garantista para el deudor hipotecario: el RD 716/2009, de 24 de abril, que estableció un límite al tipo de subasta para los préstamos o créditos susceptibles de ser titulizados en el mercado hipotecario- que no podría ser inferior al $100 \%$ del valor de la tasación previa. Suscribimos aquí la opinión mantenida por Carmen Senés Montilla (cfr. «La reforma de la ejecución ordinaria e hipotecaria...», 159). 
permitirá al notario reanudar el procedimiento de venta a instancia del acreedor (artículo 129. 2 f) $\mathrm{LH})^{54}$.

1) Si bien la Ley 1/2013 refleja la necesaria incorporación del control judicial sobre el equilibrio contractual en el procedimiento hipotecario, a pesar de su carácter sumario, el legislador no ha incorporado a una norma la dación en pago forzosa para el acreedor, ni siquiera en determinados casos; no obstante, admitido este control judicial del equilibrio contractual en la ejecución hipotecaria, no faltan autores que estiman que no habría que descartar que pudiera acordarse puntualmente la dación en pago ${ }^{55}$.

${ }^{54}$ En relación a este precepto, podría estimarse (cfr. Joaquín DELGADo RAMOs, «El procedimiento extrajudicial de ejecución hipotecaria. Dudas sobre su validez y efectos», en La venta extrajudicial..., 103-120) que la regulación de la venta extrajudicial que contempla el indicado artículo 129 LH sólo se refiere a la relación interna entre las partes que otorgaron el contrato de hipoteca, y no a la ejecución de la acción real hipotecaria frente a terceros, en base entre otros razonamientos a multitud de preceptos comprensivos de principios generales del derecho, que excluyen expresamente que un pacto entre las partes pueda tener el efecto de cancelar derechos reales anotados o inscritos registralmente a favor de terceros, entre ellos el art. 1257 del Código civil y el art. 82 de la LH.

55 Así lo ha defendido D. P. ÁlAmo GonzÁLEZ, La dación en pago en las ejecuciones hipotecarias. El control judicial del equilibrio contractual (Valencia: Tirant lo Blanch, 2012), 97-110). Con referencia a la dación en pago que contempla el número 3 del Anexo del Real Decreto-ley 6/2012 al que dio nueva redacción la Ley 1/2013, de 14 de mayo, indica en cambio Álvaro NúÑEZ IGLESIAS (cfr. «Alternativa a la ejecución hipotecaria judicial», en La venta extrajudicial..., 25) que además de no ser absolutamente obligatoria para la entidad acreedora, puesto que le basta con no suscribir el CBP, debería representar una solución puramente amistosa, producto de la autonomía de las partes, sin salir nunca de ese ámbito. Y concluye el A. que se recela de la dación en pago y no en igual medida del pacto comisorio, debiendo matizarse el alcance de la prohibición del referido pacto que resulta del artículo 1859 del Código civil y reconocer su admisibilidad, con respeto del límite que supone el enriquecimiento injusto. Dicho respeto puede lograrse con una adjudicación del bien por el valor actual y total del mismo. En la actualidad, se ha optado por su permisibilidad en la Unión Europea, salvo en Alemania, Holanda, Portugal e Italia. Cfr. también Guillem SolER SolÉ, «Passat, present i futur de la problemàtica hipotecària espanyola. El control de les clausules abusives», Revista Jurídica de Catalunya 114/1 (2015), 17, quien señala que la normativa hipotecaria española siempre ha permitido la limitación de la responsabilidad hipotecaria al valor del inmueble gravado en garantía de la devolución del préstamo (art. 140 LH). De todas maneras, esta eventualidad requeriría pacto expreso entre las partes, inviable en un sector como el del consumo del crédito hipotecario para la adquisición de la vivienda, en que la desigualdad de posición y de información entre las partes (entidades bancarias y ciudadanos corrientes) implicaría prácticamente la inexistencia de este tipo de pactos... Por tanto en estos casos es aplicable el artículo $105 \mathrm{LH}$, según el cual la constitución de una hipoteca no alterará la responsabilidad personal ilimitada del deudor que establece el artículo 1.911 del Código Civil. 
m) Finalmente, según la Ley 1/2013, de 14 de mayo la solución del endeudamiento privado, que a su vez ineludiblemente provoca más endeudamiento público, debe erigirse en prioridad legislativa y su tratamiento debe ser abordado, desde una perspectiva multidisciplinar: LEC, Ley Concursal (LC) y Ley Orgánica de Protección de datos personales ${ }^{56}$.

m.1) Con referencia a la LEC, la Ley $1 / 2013$, de 14 de mayo, parece que no ha abordado con mucho éxito el problema del sobreendeudamiento hipotecario, de suerte que no se ha dado el paso de exigir una nueva tasación del inmueble en el momento de la ejecución, y según el actual artículo 682 LEC, se sigue manteniendo la tasación pactada en la escritura de constitución de la hipoteca ${ }^{57}$. Por otra parte, en el artículo 579 LEC redactado por el apartado cinco del artículo 7 de la Ley 1/2013, de 14 de mayo, se prescinde de cualquier conducta del deudor y de su capacidad económica: una persona con recursos que abona el $65 \%$ de la deuda pendiente en los cinco años desde la fecha de aprobación del remate, verá exonerado el $35 \%$ de la deuda; en

${ }^{56}$ En este sentido se manifiesta Matilde CuEna CASAS, «Sobreendeudamiento del consumidor y liquidación de deudas, en La protección del deudor hipotecario...», 87 ss.

${ }^{57}$ Así se establece en el artículo 682 2. 1. que impone que «en la escritura de constitución de la hipoteca se determine el precio en que los interesados tasan la finca o bien hipotecado, para que sirva de tipo en la subasta, que no podrá ser inferior, en ningún caso, al 75 por cien del valor señalado en la tasación realizada conforme a las disposiciones de la Ley 2/1981, de 25 de marzo, de Regulación del Mercado Hipotecario», que mantiene su redacción dada por la Ley 1/2013, de 14 de mayo, tras de la modificación del número 2 del artículo 682 LEC por virtud de la Ley 19/2015, de 13 de julio. Cfr. Manuel GonZÁLEZ-MENESES GARCÍA-VALDECASAS, «La tasación de la finca hipotecada después de la ley 1/2013, de 14 de mayo», 167 ss., quien pone de relieve cómo los préstamos hipotecarios, por definición, suelen ser a largo plazo, de manera que es perfectamente posible que el valor que se atribuyó a la finca en el momento de constituirse la hipoteca sea muy diferente, tanto al alza como a la baja, del valor de mercado que la misma tenga en el momento de la ejecución. El período de tiempo transcurrido entre el momento en que se realizó la tasación del bien y aquel en que se convoca la subasta en el procedimiento de ejecución hipotecaria puede en efecto provocar diferencias sustanciales. También muy acertadamente estima Manuel Almenar Belenguer (cfr. "Cuestiones de actualidad...», 99), que n. ${ }^{\circ}$ debería haber ningún obstáculo para que el juez, de oficio o a instancia del deudor ejecutado, recabara la aportación a los autos de una nueva tasación ajustada al precio real en el momento de la subasta, corrigiendo así las posibles oscilaciones del mercado, de manera que el mínimo del $75 \%$ previsto en el art. 682 LEC se calcularía sobre esta nueva tasación. Por otra parte, lógicamente, las escrituras otorgadas con anterioridad al 15 de mayo de 2013 no cumplen con la nueva exigencia introducida en el art. 682.2.1. ${ }^{\circ}$ de la LEC relativa al respeto del límite mínimo del $75 \%$, pero no por ello, según el A., han de quedar privados de fuerza ejecutiva los títulos fechados con anterioridad. 
cambio, el que menos tiene y que no puede hacer frente a tales porcentajes de pasivo, seguirá condenado a la exclusión social.

m.2) Con relación a la Ley Concursal, tras de la reforma del artículo 178.2 de la LC por virtud de la Ley 38/2011 de 10 de octubre, se facilitaría la ejecución por parte de los acreedores que no cobraron en el procedimiento concursal, de suerte que, si no tenían un título ejecutivo, su inclusión en la lista definitiva de acreedores se equipararía a sentencia de condena firme ${ }^{58}$. Por ello no faltaron autores que estimasen que debiera quizá optarse por el establecimiento del fresh start $^{59}$, que puede favorecer que el procedimiento concluya en convenio, se evite que los concursos terminen en liquidación y se estimule una adecuada valoración del riesgo crediticio.

m.3) Con referencia finalmente a la protección de datos personales, en España a diferencia de otros países, tienen una aplicación limitada, subordinada al consentimiento del deudor, los ficheros de solvencia positivos. Sin embargo, los beneficios de compartir información crediticia no son desdeñables, por cuanto que con ello se permite adecuar el coste crediticio a la prima de riesgo y puede dotarse de mayor seguridad al mercado de alquiler. La interpretación restrictiva de la legislación en materia de protección de datos puede limitar el acceso a información financiera fiable y favorecer que cualquier medida protectora del deudor sobreendeudado genere un encarecimiento del crédito, indeseable en el contexto económico actual ${ }^{60}$.

${ }^{58}$ Este precepto que ha sido nuevamente redactado por el del R.D.-ley 1/2015, de 27 de febrero, y por virtud de la Ley 25/2015, de 28 de julio, no ha quedado modificado en relación al extremo expuesto.

${ }^{59}$ El fresh start, descubierto en USA en 1898, consiste en la exoneración del pasivo pendiente por virtud de la cual, liquidado el patrimonio del deudor de buena fe, los acreedores no pueden iniciar ejecuciones singulares pues el pasivo pendiente ha sido exonerado. Como recuerda Álvaro NúÑEZ IGLESIAS, (cfr. "Alternativa a la ejecución hipotecaria judicial», en La venta extrajudicial..., 1-31), el Derecho danés fue el primero en introducir el fresh start en Europa en 1984. Después de Dinamarca otros muchos países serían conscientes de la necesidad de encaminar su legislación hacia procedimientos específicos para rehabilitar al consumidor insolvente como Reino Unido, Francia, Noruega, Austria, Luxemburgo.... Indudablemente indica el A., sea cual sea la concepción, los Derechos europeos -incluido el español- están llamados a converger con relación al fenómeno del endeudamiento excesivo. Cfr. asimismo Francisco J. ANDRÉs SANTOS, «Procedimientos relativos al sobreendeudamiento de particulares en el Derecho europeo» en La protección del deudor hipotecario..., 139 ss.

${ }^{60}$ Cfr. Cfr. Matilde CuEna CASAS, «Sobreendeudamiento del consumidor y liquidación de deudas», en La protección del deudor hipotecario..., 96-98. 
5. Después de la promulgación, de la Ley $1 / 2013$, de 14 de mayo, aún fueron muchos los que afirmaron que la reforma que supone dicho texto legal, impulsada por la Sentencia de 14 de marzo de 2013 del TJUE, fue parcial e insuficiente ${ }^{61}$ y que estiman que la expresada disposición representa una oportunidad perdida de realizar una modificación profunda del sistema que supusiese un verdadero reequilibrio de las posiciones de deudor y acreedor, optando el legislador por el mantenimiento de los principios básicos del sistema de ejecución ${ }^{62}$. En esta misma orientación doctrinal hay quien estima que la ley no altera el procedimiento de ejecución hipotecaria, sino que simplemente paraliza el lanzamiento, además de que durante el tiempo que dure la suspensión se siguen devengando intereses de demora. La dación en pago sigue contemplándose tan sólo como una posibilidad de adhesión voluntaria para las Entidades de Crédito al CBP, siempre que no se haya producido el anuncio de la subasta, como último recurso en el caso de que no haya resultado viable el plan de reestructuración de la deuda, y cumplidos determinados requisitos que bien pueden calificarse de rigurosamente muy exi-

${ }^{61}$ Cfr. Soraya Callejo Carrión / Mercedes De Prada Rodríguez, «Urge un consentimiento informado (que . $^{\circ}$ desinformado) para la ejecución hipotecaria», Diario La Ley 8602, Sección Tribuna (10 de Septiembre de 2015), 1-11, quienes estiman que la necesidad de reforma venía avalada fundamentalmente por la certeza de que había que acometer la regulación de la ejecución judicial hipotecaria desde una perspectiva eminentemente procesalista y no civilista o, más concretamente, hipotecarista, y, por otra parte, porque el desequilibrio entre las partes, consustancial a todo proceso de ejecución, pero intolerable cuando se torna en verdadera indefensión para una de ellas, el ejecutado, exigía, en verdad, un reforzamiento de su posición en el proceso, sin menoscabar los derechos del acreedor hipotecario, pero echan de menos la pronta implantación de un auténtico consentimiento informado que garantice al consumidor un conocimiento exacto de lo que firma y de las consecuencias aplicables a su relación crediticia con el banco, así como la tutela de una manera efectiva de los derechos e intereses del consumidor, desde antes del inicio de la ejecución hipotecaria, garantizando una real negociación contractual y una información veraz y precisa de lo que se acepta y firma, y de las consecuencias derivadas de todo ello.

62 En este sentido se manifiesta Ana Suyapa Fernández-SAncho Tahoces (cfr., «Derecho a la vivienda y ejecución hipotecaria: valoración de las recientes reformas legales», Diario La Ley 8529, Sección Doctrina (29 de Abril de 2015), 1-23). También indica Rosa Catena (cfr. op. cit. 26-27) que las distintas reformas legislativas que precedieron al 2014, llevadas a cabo para dotar de protección al deudor hipotecario, han resultado del todo insuficientes, por cuanto que se parte de una ausencia de regulación del sobreendeudamiento del consumidor en nuestro país, sobreendeudamiento que trae causa, en el deudor hipotecario, de la concesión irresponsable del crédito por parte de las entidades financieras y que se materializa en una tasación de los inmuebles por sociedades de tasación que en absoluto eran independientes de las entidades financieras. Y considera absolutamente necesario fomentar una concesión responsable del crédito con la previa evaluación de solvencia del deudor. 
gentes. Y si bien es cierto que al amparo de la Ley $1 / 2013$ se concedieron quitas en caso de existir deuda pendiente tras la ejecución (del $35 \%$ si se abona en 5 años y del $20 \%$ si se hace en diez), no se estableció un sistema de segunda oportunidad, a semejanza del de otros países de nuestro entorno como Francia o Alemania. La Ley 1/2013 a pesar del aumento del porcentaje de adjudicación al acreedor hipotecario, que en teoría supone la reducción de la deuda tras la ejecución, seguía en efecto anclada en la responsabilidad patrimonial universal del deudor.

\section{EL RDL 1/2015 DE 27 DE FEBRERO Y LA LEY 25/2015, DE 28 DE JULIO. LA SITUACIÓN DEL DEUDOR HIPOTECARIO EN LA ACTUALIDAD. CONCLUSIONES Y REFLEXIONES}

1. La Ley 14/2013 de Emprendedores introdujo por primera vez en nuestro Derecho mecanismos de exoneración de deudas o de segunda oportunidad, aunque tuvo muy escasa aplicación práctica debido al rigor de los requisitos exigidos ${ }^{63}$. La referida Ley permitió a priori al «empresario de responsabilidad limitada» (ERL) excluir de la responsabilidad patrimonial la vivienda por deudas empresariales; y en los casos de insolvencia extinguir las deudas tras la liquidación del patrimonio ${ }^{64}$, confiriendo asimismo una nueva redacción al art. 178.2. ${ }^{\circ}$ LC $^{65}$. Los posteriores RDL 4/2014 de 7 de

${ }^{63}$ Cfr. Pedro-Luis Viguer Soler, «Análisis crítico del RDL 1/2015 sobre «segunda oportunidad»: expectativas, luces y sombras», Diario La Ley 8592, Sección Doctrina (29 de Julio de 2015), 1-28.

${ }^{64}$ En este sentido, establece el Artículo 8 de la Ley 14/2013, de 27 de septiembre: «1. Por excepción de lo que disponen el artículo 1.911 del Código Civil y el artículo 6 del Código de Comercio, el Emprendedor de Responsabilidad Limitada podrá obtener que su responsabilidad y la acción del acreedor, que tenga origen en las deudas empresariales o profesionales, no alcance al bien no sujeto con arreglo al apartado 2 de este artículo y siempre que dicha no vinculación se publique en la forma establecida en esta Ley.2. Podrá beneficiarse de la limitación de responsabilidad la vivienda habitual del deudor siempre que su valor no supere los 300.000 euros, valorada conforme a lo dispuesto en la base imponible del Impuesto sobre Transmisiones Patrimoniales y Actos Jurídicos Documentados en el momento de la inscripción en el Registro Mercantil. En el caso de viviendas situadas en población de más de 1.000.000 de habitantes se aplicará un coeficiente del 1,5 al valor del párrafo anterior».

${ }^{65}$ El apartado 2 del artículo 178 LC pasaría a tener la siguiente redacción: «2. La resolución judicial que declare la conclusión del concurso del deudor persona natural por liquidación de la masa activa declarará la remisión de las deudas insatisfechas, siempre que el concurso no hubiera sido declarado culpable ni condenado por el delito previsto por el artículo 260 del Código Penal o por cualquier otro delito singularmente relacionado con el concurso y que hayan sido satisfechos en su integridad los créditos contra la masa, y los créditos concursales privilegiados y, al menos, el 25 por ciento del importe de los créditos 
marzo, de medidas urgentes en materia de refinanciación y reestructuración de deuda empresarial, RDL 11/2014 de 5 de septiembre, y la Ley 9/2015 de medidas urgentes en materia concursal, no contuvieron por otra parte más que disposiciones pensadas para facilitar todas ellas la continuidad de empresas de cierta entidad, y no para favorecer al empresario individual o al consumidor sobreendeudados ${ }^{66}$.

2. El 28 de febrero de 2015 se publicó en el BOE el RDL 1/2015 de 27 de febrero, «de mecanismo de segunda oportunidad, reducción de carga financiera y otras medidas de orden social», que ampliaría y flexibilizaría el sistema precedente. El artículo 178 bis de la LC introducido por el citado RDL

concursales ordinarios. Si el deudor hubiere intentado sin éxito el acuerdo extrajudicial de pagos, podrá obtener la remisión de los créditos restantes si hubieran sido satisfechos los créditos contra la masa y todos los créditos concursales privilegiados».

${ }^{66}$ La expresada Ley 9/2015 de 25 de mayo sí que posibilita, en cambio, al deudor hipotecario interponer recurso de apelación contra el auto que desestime su oposición a la ejecución, si ésta se hubiera fundado en la existencia de una cláusula contractual abusiva. Hasta entonces, el artículo 695 LEC vetaba al ejecutado la posibilidad de interponer el referido recurso. En efecto, después de que el pasado 17 de Julio de 2014, el TJUE dictase una Sentencia a raíz de una petición de decisión prejudicial planteada por la AP de Castellón sobre la interpretación del Art. 7.1 de la Directiva 93/13 /CEE del Consejo, de 5 de Abril de 1993, sobre las cláusulas abusivas en los contratos celebrados con consumidores, en relación con el artículo 47 de la Carta de los Derechos Fundamentales de la Unión Europea, sería nuevamente redactado el apartado 4 del artículo 695 de la LEC que en la actualidad dispone: «4. Contra el auto que ordene el sobreseimiento de la ejecución, la inaplicación de una cláusula abusiva o la desestimación de la oposición por la causa prevista en el apartado $1.4 .^{\circ}$ anterior, podrá interponerse recurso de apelación. Fuera de estos casos, los autos que decidan la oposición a que se refiere este artículo no serán susceptibles de recurso alguno y sus efectos se circunscribirán exclusivamente al proceso de ejecución en que se dicten». Sobre los problemas procesales y las soluciones para incorporar el control en la ejecución hipotecaria, vid. por todos: Carrasco Perera, A., «La Ley $1 / 2013$, de 14 de mayo, de reforma hipotecaria y la articulación procesal del control sobre cláusulas abusivas en la ejecución hipotecaria», en Revista CESCO de Derecho de Consumo (2013), en: <http://www.revista.uclm.es/index.php/cesco/>. Señalaremos finalmente que como indica Juan Manuel Rodríguez CÁrCAMo (cfr. «Los asuntos Sánchez Morcillo: el recurso de apelación en el procedimiento de ejecución hipotecaria y el Derecho de la UE», Diario La Ley 8613, Sección Tribuna (25 de Septiembre de 2015)), el Auto del TJUE Sánchez Morcillo II (C-539/14), dictado el pasado 16 de julio de 2015, ha declarado que el actual artículo 695.4 LEC, en la redacción dada por el Real Decreto-ley $11 / 2014$ ), en el que se regula el sistema de recursos en el procedimiento de ejecución hipotecaria, es una disposición conforme al Derecho de la UE (la redacción del 2015 que hemos reproducido, literalmente coincide con la precitada). Con esta decisión, el TJUE confirma que el actual procedimiento de ejecución hipotecaria español, tras las sucesivas reformas experimentadas desde la sentencia Aziz (C-415/11) y, en particular, su sistema de recursos, concede al consumidor una protección compatible con la Directiva 93/13 sobre cláusulas abusivas. 
1/2015, y nuevamente redactado por virtud de la Ley 25/2015, de 28 de julio contempla la exoneración del pasivo pendiente o fresh start. El RDL 1/2015 parte de tres conceptos que son sus pilares fundamentales: 1) el concepto de deudor de buena fe, que la Ley delimita con cuidado en el art. 178 bis $3 .^{\circ}$ LC, pues el beneficio de exoneración de deudas sólo está reservado a deudores honestos ${ }^{67}$; 2) el acuerdo extrajudicial de pagos, que es el paso previo prácticamente ineludible (aunque no siempre, art. 178 bis $3 .^{\circ}, 4 .^{\circ}$ y $5 .^{\circ}$ LC); y 3 ) finalmente, la exoneración, remisión o condonación de las deudas, siempre que se cumplan ciertos requisitos, una vez liquidado el patrimonio del deudor o acreditada su insuficiencia. Para ello el RDL 1/2015 crea un procedimiento cuyo esquema podría ser el siguiente: 1) comienza como regla general, con el intento de acuerdo extrajudicial (que es obligatorio como paso previo, salvo que se dé el supuesto del núm. 4 del apartado $3 .^{\circ}$ del art. 178 LC) ${ }^{68}$; 2) si dicho acuerdo no se consigue, se pasa a la fase de concurso consecutivo, y directamente si se trata de personas físicas no comerciantes, a la fase de liquidación de su patrimonio; 3) liquidado el patrimonio o en caso de insuficiencia del mismo, el deudor puede solicitar la exoneración de deudas si ha satisfecho una parte de ellas (los créditos contra la masa, los concursales privilegiados o al menos el $25 \%$ de los créditos concursales ordinarios); 4) alternativamente puede pedir la exoneración provisional de sus deudas presentando un plan de pagos de las deudas restantes (las no exonerables); 5) si se aprueba el plan, se puede obtener la exoneración provisional de deudas; 6) Las deudas no exonerables deberán ser satisfechas por el concursado dentro de los cinco años siguientes a la conclusión del concurso, salvo que tuvieran un vencimiento posterior, o al menos deberá dedicar a su pago el $50 \%$ o el

${ }^{67}$ Los requisitos exigidos para reconocer la buena fe en el deudor coinciden algunos con los establecidos en la anterior regulación que contemplaba el artículo 178. 2, redactado por virtud de la Ley 14/2013 de Emprendedores (como por ejemplo que el concurso no haya sido declarado culpable, o que se haya satisfecho en su integridad los créditos contra la masa, y los créditos concursales privilegiados), mientras que en otros casos la norma es mucho más restrictiva, y exige para que el deudor sea considerado de buena fe, que no haya sido ni condenado en sentencia firme por delitos contra el patrimonio, contra el orden socioeconómico, falsedad documental, contra la Hacienda Pública y la Seguridad Social o contra los derechos de los trabajadores en los 10 años anteriores a la declaración de concurso.

${ }^{68}$ Es decir, que se hayan satisfecho los créditos contra la masa, los privilegiados y el $25 \%$ de los ordinarios, en cuyo caso no sería necesario intentar previamente el acuerdo extrajudicial de pagos. De este modo se salva la aparente contradicción entre los números $3 .^{\circ}$ y $4 .^{\circ}$ del apartado $3 .^{\circ}$ del art. $178 \mathrm{LC}$. Con referencia al acuerdo extrajudicial de pagos, la nueva regulación parte del acuerdo extrajudicial introducido por Ley 14/2013 como paso previo, sólo que ahora se flexibilizan algo sus requisitos y se amplía tanto su ámbito subjetivo (ya que se extiende a todas las personas físicas sean o no empresarios) como objetivo (se amplía el posible contenido del acuerdo). 
$25 \%$ de los ingresos que no sean inembargables cuando en este último supuesto, concurriesen en el deudor las circunstancias excepcionales previstas en el artículo 3.1, letras a) y b), del Real Decreto-ley 6/2012, de 9 de marzo; 7) Si se cumplen estas condiciones se declara la remisión definitiva de las deudas ${ }^{69}$.

El RDL 1/2015 pretendió dar una respuesta global frente al sobreendeudamiento y solventar el agravio comparativo que desde siempre ha existido entre el tratamiento que la Ley depara a la insolvencia de las personas jurídicas, por un lado, y a la de las personas físicas por otro. La determinación de la insuficiencia de bienes y derechos del concursado (y de los terceros responsables subsidiarios) con que poder satisfacer a los acreedores, en cualquier estadio del procedimiento, es causa de la conclusión del concurso y del archivo de actuaciones (art. 176.1. 3. ${ }^{\circ} \mathrm{LC}$ en la actualidad subsistente). En el caso de personas jurídicas, esto conduce a la extinción de la personalidad jurídica del concursado (art. 178. 3 LC). Éste ya no podrá adquirir más bienes ni contraer nuevas deudas como tal persona jurídica, y las deudas pendientes quedan igualmente extinguidas, por falta de sujeto pasivo a quien imputárselas. Si se reabriera el concurso, se limitaría a la liquidación de los bienes aparecidos con posterioridad al cierre del concurso anterior. Por el contrario, en el caso del concurso de un deudor persona física, la circunstancia de la insuficiencia de la masa activa no produce las mismas consecuencias, sino que subsiste la responsabilidad personal e ilimitada ex art. $1911 \mathrm{CC}$ por las deudas insatisfechas tras la liquidación y los acreedores podrán iniciar ejecuciones singulares en tanto no se declare la reapertura del concurso o no se declare un nuevo concurso ${ }^{70}$.

${ }^{69}$ En materia de exoneración deudas y segunda oportunidad, la principal novedad del RDL $1 / 2015$ es que en sus arts. 176 bis y 178 bis amplía notablemente el régimen de exoneración de la Ley 14/2013 de Emprendedores con una regulación mucho más completa de esta excepción al principio de responsabilidad patrimonial universal del art. 1911 Código Civil, que puede obtener el deudor en dos supuestos: cuando hayan concluido las operaciones de liquidación o bien cuando su patrimonio (masa activa) sea insuficiente para satisfacer sus deudas; y puede hacerlo dentro, bien del plazo de rendición de cuentas del art. 152.3. ${ }^{\circ} \mathrm{LC}$, bien en trámite de audiencia por insuficiencia de la masa activa del art. 176 bis LC (cfr. José M. ${ }^{a}$ FERNÁNDEZ SEIJO, «Aspectos concursales de la Ley de segunda oportunidad», Diario La Ley 8500, Sección Doctrina (13 de Marzo de 2015), 1-14).

${ }^{70}$ En este sentido se manifiesta el art. 178.2 LC, redactado por el número uno del apartado primero del artículo 1 de Ley 25/2015, de 28 de julio, sin que la nueva redacción haya afectado a la materia que nos ocupa (cfr. Francisco J. ANDRÉS SANTOS, «La reforma del derecho concursal», en Le obbligazionioni e i contratti... 107 y 108). No existe, por tanto, ninguna clase de discharge o condonación del pasivo insatisfecho -como sí acontece en otros ordenamientos jurídicos como el norteamericano o el alemán- fuera de la discharge impropia que provendría de la eficacia novatoria del convenio con los acreedores, caso de que llegara a obtenerse. El legislador reformista de 2011 no abordó finalmen- 
La trascendente reforma introducida por el RDL 1/2015 no puede entenderse, sin embargo, sin conocer el contexto de los informes y antecedentes que a nivel internacional venían clamando por un nuevo y adecuado tratamiento del sobreendeudamiento de las personas físicas, entre los que cabe mencionar los informes del Fondo Monetario Internacional de 7 de julio de 2014 y 8 de junio de $2015^{71}$, el Dictamen del Comité Económico y Social Europeo de 29 de abril de $2014^{72}$ y la Recomendación UE de 12 de abril de 2014 sobre «nuevo enfoque frente a la insolvencia y el fracaso empresarial ${ }^{73} \gg$.

te esta cuestión y concluye el A. que si bien se han adoptado desde entonces distintas medidas paliativas de los deudores hipotecarios, $n .^{\circ}$ dejan de ser medidas puntuales y ortopédicas que no afrontan el problema en toda su dimensión global, y entre tanto, la necesaria reforma de la LC que tenga en cuenta las peculiaridades de los concursos de personas físicas no empresariales sigue esperando un legislador con una vocación más decidida de servir a los intereses de la ciudadanía en su conjunto y no tanto a los dictados de las entidades financieras. Como pone de relieve Pedro-Luis Viguer Soler (cfr. «Análisis crítico del RDL 1/2015 sobre «segunda oportunidad»: expectativas, luces y sombras», Diario La Ley 8592, Sección Doctrina (29 de Julio de 2015), 1-28) parece que el proceso concursal español nunca ha funcionado en cuanto al tratamiento de la insolvencia de las personas físicas, como lo evidencia el escasísimo uso que del referido procedimiento han realizado tanto los consumidores y familias sobreendeudados como las pequeñas empresas, en especial los empresarios individuales.

${ }^{71}$ El FMI emitió un relevante informe sobre la situación económica de España de fecha 7 de julio de 2014 en el que consideraba que la dureza de la normativa española podría ser contraproducente y recomendaba estudiar a fondo a medio plazo la aplicación del fresh start, subrayando que la perspectiva de una condena económica tan larga podía desincentivar la iniciativa empresarial y avisando de que el sistema actual podría alimentar la economía sumergida.

72 El CESE elaboró en abril de 2014 (DOUE 12 de septiembre de 2014) un interesante informe en el que se estimaba necesario prestar especial atención en el ámbito de la UE al problema del sobreendeudamiento de los consumidores y a tomar medidas a escala europea partiendo de una definición común del sobreendeudamiento y sobre todo, se incidía en la necesidad de regular un procedimiento uniforme caracterizado por la sencillez, rapidez y gratuidad, con una fase amistosa de acuerdo; también la necesidad a escala europea de excluir determinados bienes de la posibilidad de embargo o su venta a precios irrisorios, la suspensión de ejecuciones individuales, e incluso la cancelación total o parcial de la deuda en los casos más graves para evitar la exclusión social. Asimismo en el dictamen se recomendaba la búsqueda de criterios comunes en la UE para la lucha contra los intereses abusivos o usurarios así como medidas destinadas a una educación doméstica y financiera, impulsando y fomentando prácticas leales y éticas hacia un crédito responsable.

73 A diferencia del Dictamen CESE, la citada Recomendación no se refería a los consumidores y familias, sino a la insolvencia de las pequeñas empresas y a la necesidad de abordar el problema del fracaso empresarial, señalando que su objetivo es garantizar que las empresas viables con dificultades financieras, cualquiera que sea su ubicación en la 
Además de las ya mencionadas, podemos citar otras innovaciones introducidas como consecuencia del Real Decreto-ley 1/2015, de 27 de febrero, y de la Ley 25/2015, de 28 de julio, «de mecanismo de segunda oportunidad, reducción de la carga financiera y otras medidas de orden social»:

1) La nueva redacción de los artículos 3.1 y 5.2 del Real Decreto-ley 6/2012, con referencia respectivamente al ámbito del umbral de exclusión y a la aplicación del CBP a las hipotecas constituidas en garantía de préstamos o créditos para la adquisición de bienes inmuebles, en función del precio de estos últimos ${ }^{74}$,

Unión, tengan acceso a unos marcos nacionales de insolvencia que les permitan reestructurarse en una fase temprana con el fin de prevenir la insolvencia y, por lo tanto, maximizar su valor total para los acreedores, los empleados y los propietarios, así como para el conjunto de la economía», añadiendo que «la Recomendación también se propone ofrecer una segunda oportunidad a los empresarios honrados incursos en procesos de insolvencia en toda la Unión.»

74 De suerte que el artículo 3 número 1 del Real Decreto-ley 6/2012 dispone en la actualidad «que se considerarán situados en el umbral de exclusión aquellos deudores de un crédito o préstamo garantizado con hipoteca sobre su vivienda habitual, cuando concurran en ellos las circunstancias $n .^{\circ}$ de que todos los miembros de la unidad familiar carezcan de rentas derivadas del trabajo o de actividades económicas, sino que a) el conjunto de los ingresos de los miembros de la unidad familiar no supere el límite de tres, cuatro o de cinco veces, según los casos, el Indicador Público de Renta de Efectos Múltiples; b) es preciso además, que, en los cuatro años anteriores al momento de la solicitud, la unidad familiar haya sufrido una alteración significativa de sus circunstancias económicas o hayan sobrevenido en dicho período circunstancias familiares de especial vulnerabilidad; y c) que la cuota hipotecaria resulte superior al 50 o al menos al 40 por cien, según las circunstancias, de los ingresos netos que perciba el conjunto de los miembros de la unidad familiar». Y el artículo 5. 2 de la propia disposición establece: «La aplicación del Código de Buenas Prácticas se extenderá a las hipotecas constituidas en garantía de préstamos o créditos, cuando el precio de adquisición del bien inmueble hipotecado no exceda en un 20 por ciento del que resultaría de multiplicar la extensión del inmueble, por el precio medio por metro cuadrado para vivienda libre que arroje el Índice de Precios de la Vivienda elaborado por el Ministerio de Fomento para el año de adquisición del bien inmueble y la provincia en que esté radicado dicho bien, con un límite absoluto de 300.000 euros. Los inmuebles adquiridos antes del año 1995 tomarán como precio medio de referencia el relativo al año 1995. No obstante, solo podrán acogerse a las medidas previstas en el apartado 3 del Código las hipotecas constituidas en garantía de préstamos o créditos concedidos, cuando el precio de adquisición del bien inmueble hipotecado no exceda del que resultaría de multiplicar la extensión del inmueble, por el precio medio por metro cuadrado para vivienda libre que arroje el Índice de Precios de la Vivienda elaborado por el Ministerio de Fomento para el año de adquisición del bien inmueble y la provincia en que esté radicado dicho bien, con un límite absoluto de 250.000 euros. Los inmuebles adquiridos antes del año 1995 tomarán como precio medio de referencia el relativo al año 1995.» 
2) La introducción de un nuevo apartado iv en la letra b) del punto 1 del Anexo del Real Decreto-ley 6/2012 ${ }^{75}$.

3) Por otra parte, la actual redacción del artículo 1. 1. de la Ley $1 / 2013$, de 14 de mayo dada por virtud de la Ley 25/2015, de 28 de julio, sustituye el anterior plazo requerido de dos años por la Ley 1/2013, de 14 de mayo por el de cuatro desde la entrada en vigor de la Ley, para poder proceder al lanzamiento cuando en un proceso judicial o extrajudicial de ejecución hipotecaria se hubiera adjudicado al acreedor, o a persona que actúe por su cuenta, la vivienda habitual de personas que se encuentren en los supuestos de especial vulnerabilidad y en las circunstancias económicas que se detallan en este artículo.

4) $Y$ tras de las reformas llevadas a cabo en 2015 , se ha añadido a los supuestos de especial vulnerabilidad, que se contemplan en el artículo 1.2 de la precitada Ley 1/2013, de 14 de mayo, un último, el h), relativo al deudor mayor de 60 años.

3. A la vista de todo lo expuesto, cabe que nos planteemos qué reflexiones y conclusiones nos suscitan estas últimas reformas legislativas llevadas a cabo por virtud de las precitadas disposiciones del 2015, para dotar de protección al deudor hipotecario y cuál sea la situación del deudor hipotecario en la actualidad.

Sobre este particular, podríamos indicar que la nueva regulación introducida por virtud del RDL 1/2015 y complementada por virtud de la Ley $25 / 2015$, de 28 de Julio, presenta indudables aciertos al posibilitar el establecimiento de un régimen algo más flexible de exoneración de deudas para las personas físicas (consumidores o empresarios) ${ }^{76}$, siempre que sean de buena fe. Por otra parte, el acuerdo extrajudicial de pagos que antes se circunscribía

${ }^{75}$ En concreto, con la siguiente redacción: «En todo caso, se inaplicarán con carácter indefinido las cláusulas limitativas de la bajada del tipo de interés previstas en los contratos de préstamo hipotecario»».

${ }^{76}$ Y así el 27 de julio de 2015, el Directorio Ejecutivo del Fondo Monetario Internacional (FMI) concluyó la Consulta del Artículo IV con España correspondiente a 2015. En el Comunicado de Prensa N. ${ }^{\circ}$ 15/378(S) 14 de agosto de 2015, los directores señalaron que el sector financiero de España sigue fortaleciéndose, con mejoras en términos de liquidez, eficiencia y rentabilidad. Consideraron positivas las recientes reformas del régimen de insolvencia, como la aprobación de una «segunda oportunidad» para empresarios y consumidores. Si se aplican de manera efectiva y se aclaran algunos elementos clave, estas reformas pueden facilitar el desapalancamiento del sector privado, a la vez que se preserva la sólida cultura de pagos del país. Los directores respaldaron los esfuerzos para alentar a los bancos a aumentar su capital de elevada calidad y reducir los préstamos fallidos, facilitando así el crecimiento del crédito. 
a los empresarios, ahora es aplicable a todas las personas físicas ${ }^{77}$; no se establece límite alguno para las quitas en el actual artículo $236 \mathrm{LC}^{78}$, pudiendo las esperas alcanzar hasta los diez años ${ }^{79}$. Puede además obtenerse la remisión definitiva de las deudas no sólo si se cumple un plan de pagos de las no exoneradas sino también, alternativamente, si al menos el deudor ha destinado a su pago el $50 \%$ de los ingresos que no sean inembargables ${ }^{80}$. Se potencia la figura del mediador concursal cuyo nombramiento deberá recaer en la persona natural o jurídica a la que de forma secuencial corresponda de entre las que figuren en la lista oficial publicada en el portal correspondiente del «»»Boletín Oficial del Estado»»», quedando reducida la remuneración de dicho mediador hasta en un $70 \%$, si el deudor fuera una persona natural sin actividad económica (disposición adicional segunda 1 b) de la Ley 25/2015, de 28 de Julio). Además la representación por procurador no es preceptiva para el deudor persona natural en el concurso consecutivo (disposición adi-

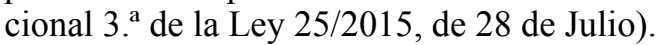

El RDL 1/2015 presenta sin embargo indudables sombras, algunas de las cuales trataron de solventarse a través de la posterior Ley 25/2015, de 28 de Julio $^{81}$. Y así según el texto inicialmente aprobado por virtud del RDL1/2015,

77 En este sentido se manifiesta el artículo 231 de la LC, tras de su última redacción dada por virtud de la Ley $25 / 2015$, de 28 de Julio, que no altera en este punto la inmediatamente precedente recibida por virtud del RDL $1 / 2015$.

${ }^{78}$ Con supresión por tanto de la anterior restricción de que no pudieran superar el $25 \%$ que prescribía el Anexo 2 B) del CBP en su redacción dada por virtud de la Ley $1 / 2013$, de 14 de mayo.

${ }^{79}$ Así se establece en el nuevo art. 236 de la LC, lo que supone una modificación del anterior límite de cinco años que contemplaba el art. 100 de la LC.

${ }^{80}$ Por cuanto que así lo posibilita el artículo 178 bis. 8, modificado por L 25/2015, de 28 de Julio.

${ }^{81}$ Sobre este particular indica P.L Viguer (Cfr. Análisis crítico... cit. p. 16) que el RDL 1/2015 parte del esquema del concurso tradicional que siempre ha contemplado la Ley Concursal, lo que presupone para las personas físicas insolventes el enfrentarse a un proceso que sigue siendo excesivamente complejo y costoso y que se aleja de las notas de sencillez, agilidad, y eficiencia que recomienda la UE, incumpliéndose asimismo las recomendaciones de la UE en orden a crear un procedimiento específico» al margen del concurso ordinario. En relación incluso a la última reforma concursal que culminaría con la Ley 25/2015, Ángel CARRASCO PERERA (cfr. «El despropósito de la «segunda oportunidad» de los consumidores sobreendeudados», Actualidad Jurídica Aranzadi 911 (2015): parte Tribuna, critica a quienes consideran que esta última haya por fin diseñado un sistema de «segunda oportunidad» para consumidores sobreendeudados. Según el autor todo el procedimiento es un despropósito, porque la innecesaria reforma nace de no preguntarse por la naturaleza de las deudas que suelen gravar a un consumidor, sin discriminar las procedentes de suministros esenciales a las que en modo alguno llegará a afectar el concurso, por haber sido ya previamente privado el consumidor por el proveedor como consecuencia del impago de servicios básicos como el agua, la electricidad, etc. 
cuando al deudor se le hubiesen condonado provisionalmente determinadas deudas, tal exoneración era revocable si en el plazo de cinco años el deudor mejorase sustancialmente su situación económica (art. 178 bis. 7 LC ${ }^{82}$ ), circunstancia que podía determinar que la exoneración resultase ser una mera ficción y nunca fuese definitiva ${ }^{83}$. En la Ley $25 / 2015$ se modificaría, sin embargo, la redacción inicial del artículo 178 bis. 7 c) LC, que sigue posibilitando la revocación de la exoneración, pero especificando las causas de la mejoría económica que puedan provocar la revocación del beneficio, y evitando de este modo que si un empresario mejora en su actividad y tiene beneficios, le sea por ello revocada la exoneración de deudas ${ }^{84}$.

${ }^{82}$ En efecto, el art. 178 bis 7 establecía que «Cualquier acreedor concursal estará legitimado para solicitar del juez del concurso la revocación del beneficio de exoneración del pasivo insatisfecho cuando el deudor, durante los cinco años siguientes a su concesión: c) Mejorase sustancialmente la situación económica del deudor de manera que pudiera pagar todas las deudas pendientes sin detrimento de sus obligaciones de alimentos». Es claro que la limitación del art. 178 bis.7.c) de la LC incentivaba que, durante cinco años, el deudor generase riqueza regularmente como mucho hasta el límite de lo que dejó sin pagar, para evitar la revocación del beneficio en función del criterio cuantitativo y que cuando pasasen esos cinco años le fuese posible, sin que ello le supusiese perjuicio alguno, generar cuanta riqueza pudiese en forma regular.

${ }_{83} \mathrm{Y}$ así para José Luis Colino MediaviLla (cfr. «Insolvencia de persona física y segunda oportunidad en el Real Decreto-ley 1/2015», Foro. Nueva época, vol. 18/ 1 (2015): 245-263, la finalidad principal del mecanismo de segunda oportunidad consiste, en que el deudor persona física que lo merezca (buena fe) no permanezca sometido a la responsabilidad por el pasivo insatisfecho de forma indefinida, sino que, por el contrario, pueda liberarse de tales deudas restantes para que la generación de riqueza mediante su trabajo o mediante el ejercicio de una actividad productiva no se vea desincentivada y para que, realizando tal esfuerzo productivo, no tenga que llevarlo a cabo de forma encubierta o irregular. Si al deudor persona física de buena fe se le exonera del pasivo insatisfecho con tal finalidad y, a la vez, se le revoca el beneficio concedido si mejora de fortuna, se incurre en una contradicción obvia, que la propia exposición de motivos del Real Decreto-ley 1/2015 reconoce en relación con lo que en su día estableció el art. 1.920 del Código Civil al que se conecta con las Partidas de Alfonso X el Sabio a través de los comentarios de Manresa. La clave es, pues, siempre para la Exposición de Motivos del Real Decreto-ley $1 / 2015$, modular la mejora de fortuna, de forma que no cualquier mejoría permita la revocación del beneficio, sino sólo una mejora que sea significativa.

${ }^{84}$ De suerte que el actual artículo 178 bis. 7 c) LC dispone que también podrá solicitarse la revocación si, durante el plazo fijado para el cumplimiento del plan de pagos, «mejorase sustancialmente la situación económica del deudor por causa de herencia, legado o donación; o juego de suerte, envite o azar, de manera que pudiera pagar todas las deudas pendientes sin detrimento de sus obligaciones de alimentos». Sobre esta temática muy justificadamente indica Matilde CUENA CASAS (cfr. «El Congreso aprueba el Proyecto de Ley de Segunda Oportunidad. El Gobierno rectifica, pero poco», ¿Hay Derecho? El blog sobre la actualidad jurídica y política, 2 julio, 2015) que la regulación precedente era ridícula carente de antecedentes en los modernos sistemas de insolvencia. La inacción 
Con referencia por otra parte a la publicidad en el Registro Público Concursal de la exoneración del pasivo insatisfecho, en el texto inicialmente aprobado por virtud del RDL 1/2015 se exigía, en el art. 178 bis. 3 LC, para la admisión de la solicitud de exoneración del pasivo insatisfecho a los deudores de buena fe, (1) que el deudor hubiese celebrado o, al menos, intentado celebrar un acuerdo extrajudicial de pagos y de no haber satisfecho en todo o en parte los créditos contra la masa en la proporción que se indicaba en el precepto; (2) que consintiese en someterse a un plan de pagos y, además, (3) que aceptase, de forma expresa, en la solicitud de exoneración, que la obtención de este beneficio se haría constar en la sección especial del Registro Público Concursal con posibilidad de acceso público, por un plazo de cinco años. Ello suponía un dato negativo en su historial crediticio que podía bloquear la obtención de futura financiación, circunstancia que podía revestir especial gravedad cuando el deudor fuese empresario, de suerte que en el actual artículo art. 178 bis.3. $.^{\circ} .5 . \mathrm{v}$, se añadiría un inciso que presupone una clara restricción del acceso al mencionado Registro ${ }^{85}$.

del deudor tenía premio: como no mejoraba su situación económica, entonces se le perdonaban definitivamente las deudas y, si le iba bien, entonces se le castigaba con la revocación de la exoneración.

${ }^{85} \mathrm{Y}$ así el actual artículo 178bis.3. ${ }^{\circ} .5 . \mathrm{v}$ dispone: «Únicamente tendrán acceso a esta sección las personas que tengan interés legitimo en averiguar la situación del deudor, entendiéndose en todo caso que tienen interés quienes realicen una oferta en firme al deudor ya sea de crédito o de cualquier otra entrega de bienes o prestación de servicios, que tenga que ser remunerada o devuelta por éste y que esté condicionada a su solvencia, asi como las Administraciones Públicas y órganos jurisdiccionales habilitados legalmente para recabar la información necesaria para el ejercicio de sus funciones. La apreciación de dicho interés se realizará por quien esté a cargo del Registro Público Concursal», Dicha restricción del acceso merece un juicio positivo, aunque siempre podríamos considerar que esta publicidad requerida es prescindible, por cuanto que dicha información puede suministrarla también la CIRBE (Central de Información de Riesgos del Banco de España), que gestiona esta misma entidad y que representa una base de datos pública, de carácter confidencial, en la que se recogen los riesgos que las entidades de crédito tienen con sus clientes, así como el artículo 42 del Reglamento de desarrollo de la Ley Orgánica 15/1999, de 13 de diciembre, de protección de datos de carácter personal, aprobado por Real Decreto 1720/2007, de 21 de diciembre. Dicho precepto establece con referencia a los Ficheros de información sobre solvencia patrimonial y crédito que los datos contenidos en el fichero común sólo podrán ser consultados por terceros cuando precisen enjuiciar la solvencia económica del afectado, considerándose que concurre dicha circunstancia en los supuestos tasados que en dicho precepto se detallan. Y además, la publicidad en el Registro Público Concursal es más punitiva para el deudor porque dura 5 años y no se hace depender del posible cumplimiento de su plan de pagos, a diferencia de los datos negativos que figuran en los ficheros de solvencia, que pueden ser cancelados en los casos de pago o cumplimiento. Así lo establece el artículo 41.1 del Reglamento de Protección de datos: Sólo podrán ser objeto de tratamiento los datos que respondan con veracidad a 
Asimismo algunas dudas que suscitaba el precedente RDL 1/2015 han quedado dilucidadas por virtud de la posterior Ley 25/2015, de 28 de Julio. En efecto, esta última disposición modificaría la anterior redacción del artículo 178 bis 5 de la LC dada por virtud del RDL 1/2015, en lo relativo a la posición de los fiadores. Una vez concedido el beneficio de exoneración del pasivo insatisfecho en el artículo 178 bis 5 de la LC se establecía que «los acreedores cuyos créditos se extinguen no podrán iniciar ningún tipo de acción dirigida frente al deudor, para el cobro de los mismos», y añadía el precepto que «quedan a salvo los derechos de los acreedores frente a los obligados solidariamente con el concursado y frente a sus fiadores o avalistas, quienes no podrán invocar el beneficio de exoneración del pasivo insatisfecho obtenido por el concursado». De suerte que la normativa anterior presuponía una excepción al principio de accesoriedad que preside las obligaciones de garantía y que contempla el artículo $1847 \mathrm{CC}$, y avalistas y fiadores seguían respondiendo de la deuda aunque hubiese sido exonerada ésta al deudor principal. En el RDL 1/2015 no quedaba claro, por tanto, lo que sucedía con la acción de reembolso, que contempla el artículo 1838 CC y que en principio, le corresponde al fiador contra el deudor una vez que haya cumplido la prestación. En la actualidad en cambio, se ha añadido un inciso al art. 178 bis 5 de forma que los fiadores u obligados solidarios no podrán «subrogarse por el pago posterior a la liquidación en los derechos que el acreedor tuviese contra aquél, salvo que se revocase la exoneración concedida ${ }^{86}$.

Por otra parte, como anteriormente indicamos, en lo que se refiere a la conducta del deudor beneficiario del régimen de segunda oportunidad, el artículo 178 bis. 3 , redactado por virtud del RDL $1 / 2015$, exigía que el concurso no hubiese sido declarado culpable, pero en cambio la Ley 25/2015, de 28 de Julio es más benevolente en este punto con el deudor, pues no se

la situación de la deuda en cada momento concreto. El pago o cumplimiento de la deuda determinará la cancelación inmediata de todo dato relativo a la misma.

${ }^{86}$ Se sigue por tanto el mismo criterio, pero ha quedado ya claro que el fiador o codeudor solidario que paga no puede en modo alguno ejercitar la acción de reembolso contra el deudor, salvo que se revoque el beneficio de exoneración. Para Matilde CuENA CASAS (cfr. «El Congreso aprueba el Proyecto....), la modificación introducida en el art. 178 bis 5 es acertada por cuanto que de esta forma, se salvaguarda la esencia de las garantías personales (ejercitables para los casos de insolvencia del deudor principal) y además se mantiene la eficacia de la exoneración del pasivo pendiente frente al deudor principal. En relación a este último extremo, coincidimos con la A. en que de este modo se mantiene la eficacia de la exoneración del pasivo pendiente frente al deudor principal, pero parcialmente discrepamos porque sin duda ello n..$^{\circ}$ deja de representar una excepción del principio contemplado en el artículo 1838 del CC que exige que el fiador que pague por el deudor sea indemnizado por éste. 
considera de mala fe y puede, por tanto, recibir la exoneración del pasivo pendiente, el deudor cuyo concurso se hubiese declarado culpable por haber incumplido el deber de solicitar la declaración del concurso ${ }^{87}$.

Otro de los posibles inconvenientes que apreciamos en la actual reglamentación es el de que quedan además excluidos los créditos públicos del vigente sistema de exoneración o de segunda oportunidad, al establecer el art. 178 bis 6 en vigor, que reproduce literalmente la redacción precedente dada por virtud de RDL 1/2015: Respecto a los créditos de derecho público, la tramitación de las solicitudes de aplazamiento o fraccionamiento se regirá por lo dispuesto en su normativa especifica, lo que supone un evidente agravio comparativo respecto del resto de acreedores.

Por otro lado, el vigente art. 231 LC. 5 en su relación con los arts. 238 y 238 bis LC exige un quórum muy elevado de acreedores (que puede llegar a alcanzar hasta el $80 \%$ ) para extender el acuerdo extrajudicial de pagos a los acreedores con garantía real ${ }^{88}$.

Estimamos además excesivo el plazo que contempla el actual artículo 178 bis. 6 coincidente en sus redacciones dadas por virtud del RDL 1/2015 y la Ley $25 / 2015$, de 28 de Julio, para la exoneración de las deudas que no

${ }^{87}$ En efecto, art. 178 bis.3.1. ${ }^{\circ}$ después de añadírsele un inciso, en la actualidad establece lo siguiente: «3. Solo se admitirá la solicitud de exoneración del pasivo insatisfecho a los deudores de buena fe. Se entenderá que concurre buena fe en el deudor siempre que se cumplan los siguientes requisitos: $1 .^{\circ}$ Que el concurso no haya sido declarado culpable. No obstante, si el concurso hubiera sido declarado culpable por aplicación del artículo $165.1 .1 .^{\circ} \mathrm{el} \mathrm{juez}$ podrá no obstante conceder el beneficio atendidas las circunstancias y siempre que no se apreciare dolo o culpa grave del deudor». La medida del legislador en este punto estimamos que es discutible, por cuanto que la declaración tardía del concurso de acreedores puede determinar la inviabilidad del acuerdo extrajudicial de pagos y que ello, en definitiva, redunde en perjuicio de los intereses de los acreedores.

${ }^{88}$ En efecto, de acuerdo con lo establecido en el actual art. 231.5 LC-cuya redacción coincide en este punto con la precedente dada por virtud del RDL 1/2015-, los créditos con garantía real se verán afectados por el acuerdo extrajudicial conforme a lo dispuesto por los artículos 238 y 238 bis, y los créditos de derecho público no podrán en ningún caso verse afectados por el acuerdo extrajudicial, aunque gocen de garantía real. Y según el artículo 238 bis: «2. Los acreedores con garantía real, por la parte de su crédito que no exceda del valor de la garantía, únicamente quedarán vinculados por el acuerdo si hubiesen votado a favor del mismo. 3. No obstante, los acreedores con garantía real que no hayan aceptado el acuerdo, por la parte de sus créditos que no excedan del valor de la garantía, quedarán vinculados a las medidas previstas en las letras a) y b) del apartado 1 del artículo anterior, siempre que las mismas hayan sido acordadas, con el alcance que se convenga, por las siguientes mayorías, calculadas en función de la proporción del valor de las garantías aceptantes sobre el valor total de las garantías otorgadas: a) Del 65 por ciento, cuando se trate de las medidas previstas en el apartado 1 a) del artículo anterior. b) Del 80 por ciento, cuando se trate de las medidas previstas en el apartado $1 \mathrm{~b}$ ) del artículo anterior». 
hubiesen quedado exoneradas conforme a lo dispuesto en el apartado anterior $^{89}$ y que es de 5 años, salvo que tuvieran un vencimiento posterior. Así lo puso de relieve la Recomendación de la Comisión de 12 de marzo de 2014 sobre un nuevo enfoque frente a la insolvencia y el fracaso empresarial en que se señaló que los efectos negativos de la insolvencia para los empresarios deberían limitarse a fin de darles una segunda oportunidad, debiendo condonarse a los empresarios totalmente las deudas incursas en la insolvencia en un plazo máximo de tres años.

Por otro lado, con relación a los efectos de la iniciación del expediente, la regla general que contempla el artículo 235. $2 \mathrm{LC}$, coincidente en su redacciones dadas por virtud del RDL 1/2015 y la Ley 25/2015, de 28 de Julio, es que la solicitud inicial del acuerdo extrajudicial de pagos no suspende la ejecución correspondiente a los créditos privilegiados (créditos con garantía real $)^{90}$, extremo que asimismo parece alejarse del espíritu de la precitada Recomendación de 12 de marzo de $2014^{91}$.

$\mathrm{Y}$ finalmente podemos indicar que el acuerdo extrajudicial de pagos representa un requisito previo ineludible para la admisión de la solicitud del deudor de exoneración del pasivo insatisfecho, de conformidad con lo establecido en el artículo 178 bis 3, 3. ${ }^{092}$, y el contenido del mismo solo será vinculante para los acreedores como ya indicamos con sujeción a lo precep-

${ }^{89} \mathrm{El}$ apartado 5 del artículo 178 bis se refiere, en concreto $\left(1 .^{\circ}\right)$ a los créditos ordinarios y subordinados pendientes a la fecha de conclusión del concurso, aunque no hubieran sido comunicados, exceptuando los créditos de derecho público y por alimentos, y $\left(2 .^{\circ}\right)$ a los créditos privilegiados.

${ }^{90}$ En este sentido dispone el artículo 235. 2 a) LC: «Desde la comunicación de la apertura de las negociaciones al juzgado competente para la declaración del concurso, los acreedores que pudieran verse afectados por el posible acuerdo extrajudicial de pagos: a) no podrán iniciar ni continuar ejecución judicial o extrajudicial alguna sobre el patrimonio del deudor mientras se negocia el acuerdo extrajudicial hasta un plazo máximo de tres meses. Se exceptúan los acreedores de créditos con garantía real que no recaiga sobre bienes o derechos que resulten necesarios para la continuidad de la actividad profesional o empresarial del deudor ni sobre su vivienda habitual».

${ }_{91}$ En la mencionada Recomendación, con carácter general y sin excepciones, se indica que el deudor podría solicitar del órgano jurisdiccional la suspensión de las acciones de ejecución individuales y del procedimiento de insolvencia cuya incoación haya sido solicitada por los acreedores cuando tales medidas puedan afectar negativamente a las negociaciones y ensombrecer las perspectivas del proceso de reestructuración de la empresa del deudor.

${ }_{92}$ En este sentido, dispone el actual artículo 178 bis 3 3.०: «Solo se admitirá la solicitud de exoneración del pasivo insatisfecho a los deudores de buena fe. Se entenderá que concurre buena fe en el deudor siempre que se cumplan los siguientes requisitos: 3. ${ }^{\circ} 3 .^{\circ}$ Que, reuniendo los requisitos establecidos en el artículo 231, haya celebrado o, al menos, intentado celebrar un acuerdo extrajudicial de pagos». 
tuado en los artículos 238 y 238 bis de la LC. Son muy escasos los poderes del juez a la hora de exonerar deudas, a diferencia de lo que ocurre en otros países como EE.UU., donde el tribunal puede aprobar el plan de pagos o imponer el que se elabore aun en contra de la voluntad de los acreedores ${ }^{93}$.

TITLE: Approximation to the protection legislation of the mortgage debtor

RESUMEN: En el presente trabajo pretendemos hacer un análisis descriptivo y crítico de las distintas reformas legislativas adoptadas en los últimos años, de grave crisis económica en España, encaminadas a deparar al deudor hipotecario la necesaria protección, partiendo de la primera iniciativa representada por el Real Decreto-Ley 8/2011, de 1 de Julio, hasta culminar con las más recientes disposiciones en el momento de escribir estas páginas: el RDL 1/2015 de 27 de febrero y la Ley 25/2015,

${ }_{93}$ En EEUU en efecto, las facultades en materia de quiebras son tan amplias que pueden presuponer tanto la aprobación de un plan que no obtuvo las mayorías requeridas (cram down) como el rechazo de uno que sí las obtuvo, pero en el que no se cumplimentaron los requisitos exigidos para la aprobación del mismo por el tribunal (Bankruptcy Court) (cfr. § 1129 Bankruptcy Code (modificado en 2005 y 2010: cfr. Douglas BAIRD, Elements of Bankruptcy (3rd ed., NY: Fundation Press, 2001), 27, y también Claudio Bonilla, Ronald Fischer, Rolf LÜDERs, Rafael MERY, José TAGLE, «Análisis y Recomendaciones para una Reforma de la Ley de Quiebras», Universidad Diego Portales. Law and Economics (sept. 2003), 1-96). En Francia, en cambio se ha pasado de un sistema caracterizado por una amplia discrecionalidad para los jueces a la hora de resolver los términos del plan de reestructuración de la deuda y la posibilidad de conceder el discharge al deudor a un sistema administrativo, regido por reglas estrictas y claras para acreedores y deudores y escaso margen de discrecionalidad judicial (cfr. Francisco J. ANDRÉs SANTOS, «Procedimientos relativos al sobreendeudamiento de particulares en el Derecho europeo» en La protección del deudor hipotecario..., 99 ss.) y que se encuentra actualmente contemplado en los artículos L.330-1 a L.334-12 y R.331-1 a R.335-4 del Code de la Consommation, cuyo origen fue la Loi Neiertz, y complementando este sistema con posterioridad, la Loi Borloo (Loi . $^{\circ}$ 2003-710), conocida como «ley de la segunda oportunidad», del 2003 y la Loi Lagarde del 2010 Loi núm. 2010-737), la Loi n. ${ }^{\circ} 2013-672$, de 26 de julio 2013, de séparation et régulation des activités bancaire y, finalmente, y el Décret n. ${ }^{\circ}$ 2014-190, de 21 de febrero 2014, relatif aux procédures de traitement des situations de surendettement des particuliers. El legislador francés ha tenido en cuenta la situación subjetiva del deudor: si éste es de buena fe, podrá beneficiarse de un aplazamiento o de la «reprogramación» de sus deudas mediante un convenio o acuerdo negociado con sus acreedores (Plan conventionnel de redressement). Si la situación del deudor es de tal gravedad que no resulta posible establecer un plan de pagos o, una vez acordado, la situación deviene imposible, se podrá orientar el procedimiento de sobreendeudamiento hacia un procedimiento de «recuperación personal» (rétablissement personnel), con o sin liquidación judicial (cfr. Rocío LóPEZ SAN LUIS, «El tratamiento del sobreendeudamiento de los particulares en Francia», Revista de Derecho Civil, vol. II/2 (abril-junio, 2015): 207228). 
de 28 de julio. Estimamos que resulta indispensable un examen exhaustivo de todas ellas para alcanzar a dilucidar si, fundamentalmente a lo largo de la última legislatura en España (2012-2015), se ha ultimado o no el objetivo de conferir al deudor hipotecario la protección adecuada en estos tiempos de crisis extremadamente convulsos y complejos, que han tenido una especial incidencia precisamente en el ámbito del mercado inmobiliario y el sobreendeudamiento de particulares.

PALABRAS CLAVE: deudor hipotecario, RDL 1/2015, Ley 25/2015, mercado inmobiliario

ABSTRACT: In the present work we intend to make a descriptive and critical analysis of the different legislative reforms adopted in recent years, of serious economic crisis in Spain, aimed at providing the mortgage debtor the necessary protection, starting from the first initiative represented by Royal Decree-Law 8/2011, of July 1, to culminate with the most recent provisions at the time of writing these pages: RDL 1/2015 of February 27 and Law 25/2015, of July 28. We consider that it is essential to carry out a comprehensive review of all of them in order to ascertain whether, essentially during the last parliamentary term in Spain (2012-2015), the objective of granting the mortgage debtor adequate protection in these times has been finalized Of extremely convulsive and complex crises that have had a special impact precisely in the real estate market and overindebtedness of private individuals.

KEY WORDS: mortgage debtor, RDL 1/2015, Ley 25/2015, real estate market

RECIBIDO: 18.04 .2016

ACEPTADO: 19.12 .2016 